\title{
Occurrence of Pesticides in Water and Sediment Collected from Amphibian Habitats Located Throughout the United States, 2009-2010
}

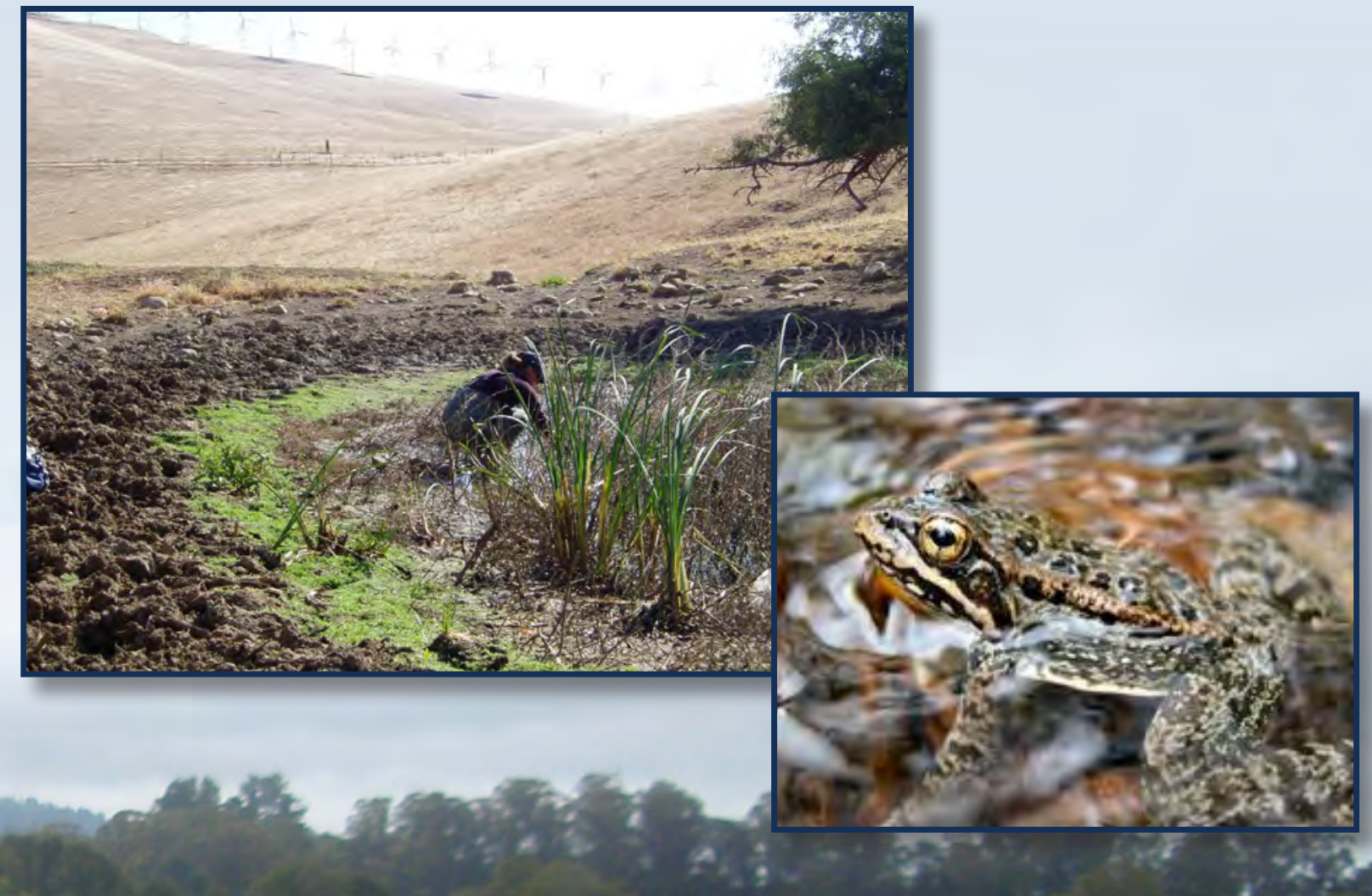

Data Series Report 707 
Cover: Photographs of U.S. Geological Survey amphibian monitoring sites in Livermore and Olema California (Photographs taken by James Orlando, US Geological Survey,

Sacramento, California, 2010) and photograph of a Cascades frog in a northern

California creek (Photograph taken by Gary Fellers, US Geological Survey, Point Reyes, California). 


\section{Occurrence of Pesticides in Water and Sediment Collected from Amphibian Habitats Located Throughout the United States, 2009-10}

By Kelly L. Smalling, James L. Orlando, Daniel Calhoun, William A. Battaglin, and Kathryn M. Kuivila

Data Series 707 


\title{
U.S. Department of the Interior \\ KEN SALAZAR, Secretary \\ U.S. Geological Survey \\ Marcia K. McNutt, Director
}

\author{
U.S. Geological Survey, Reston, Virginia: 2012
}

For more information on the USGS - the Federal source for science about the Earth, its natural and living resources, natural hazards, and the environment, visit http://www.usgs.gov or call 1-888-ASK-USGS.

For an overview of USGS information products, including maps, imagery, and publications, visit http://www.usgs.gov/pubprod

To order this and other USGS information products, visit http://store.usgs.gov

Any use of trade, product, or firm names is for descriptive purposes only and does not imply endorsement by the U.S. Government.

Although this report is in the public domain, permission must be secured from the individual copyright owners to reproduce any copyrighted materials contained within this report.

Suggested citation:

Smalling, K.L., Orlando, J.L., Calhoun, Daniel, Battaglin, W.A., and Kuivila, K.M., 2012, Occurrence of pesticides in water and sediment collected from amphibian habitats located throughout the United States, 2009-10: U.S. Geological Survey Data Series 707, 40 p. 


\section{Contents}

Abstract
Introduction
Purpose and Scope
Study Design
Timing of Sample Collection
Descriptions of Watersheds and Sampling Sites throughout the United States
California
Colorado
Georgia
Idaho
Louisiana
Maine
Oregon




\section{Contents-Continued}

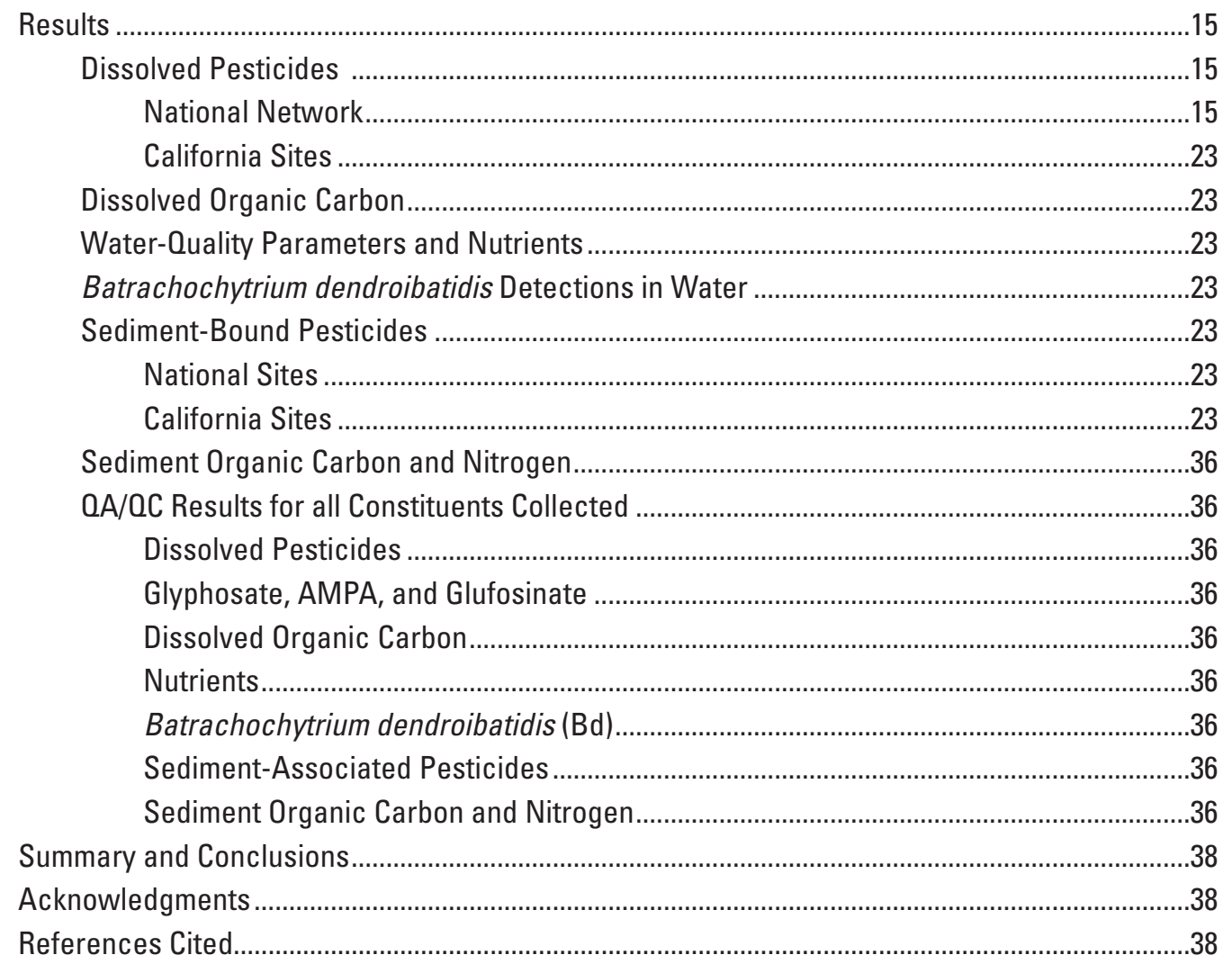




\section{Figures}

1. Map showing location of sites sampled in California, 2009-10 …...............................

2. Map showing location of sampling sites in Colorado, Georgia, Idaho, Louisiana, Maine, and Oregon, 2009-10 ..............................................................

3. Graph showing maximum numbers of pesticides detected in water and sediment samples collected from sites in seven states during 2009 and 2010......................15

\section{Tables}

1. Descriptive information for sampling sites located in California, 2009-10 _..................5

2. Descriptive information for sites located in Colorado, Georgia, Idaho, Louisiana, Maine, and Oregon, 2009-10..............................................................

3. Method detection limits for insecticides and herbicides in water and sediment. .12

4. Method detection limits for fungicides in water and sediment . .13

5. Dissolved pesticides concentrations in samples collected from California, Colorado, Georgia, Idaho, Louisiana, Maine, and Oregon, 2009-10

6. Dissolved concentrations of aminomethylphosphonic acid and glyphosate in samples collected from California, Colorado, Georgia, Idaho, Louisiana, Maine, and Oregon, 2009-10

7. Water-quality parameters measured at sampling sites located in California, 2009-10

8. Water-quality parameters and nutrients measured at sampling sites located in Colorado, Georgia, Idaho, Louisiana, Maine, and Oregon, 2009-10..

9. Nutrient concentrations in water collected from sampling sites located in California, 2009-10

10. Batrachochytrium dendrobatidis in surface water collected from sites in California, Colorado, Georgia, Idaho, Louisiana, Maine, and Oregon, 2009-10

11. Pesticide concentrations in bed sediment samples collected from California, Colorado, Georgia, Idaho, Louisiana, Maine, and Oregon, 2009-10 .30

12. Percent organic carbon and nitrogen in bed sediment collected from California, Colorado, Georgia, Idaho, Louisiana, Maine, and Oregon, 2009-10 .......37 


\section{Conversion Factors, Datums, and Abbreviations}

SI to Inch/Pound

\begin{tabular}{lcl}
\hline \multicolumn{1}{c}{ Multiply } & By & \multicolumn{1}{c}{ To obtain } \\
\hline centimeter $(\mathrm{cm})$ & Length & \\
millimeter $(\mathrm{mm})$ & 0.3937 & inch (in.) \\
micrometer $(\mu \mathrm{m})$ & 0.03937 & inch (in.) \\
meter $(\mathrm{m})$ & 0.00003937 & inch (in.) \\
kilometer $(\mathrm{km})$ & 3.281 & foot $(\mathrm{ft})$ \\
& 0.6214 & mile $(\mathrm{mi})$ \\
\hline square meter $\left(\mathrm{m}^{2}\right)$ & Area & \\
hectare $(\mathrm{ha})$ & 0.0002471 & acre \\
square kilometer $\left(\mathrm{km}{ }^{2}\right)$ & 0.003861 & square mile $\left(\mathrm{mi}^{2}\right)$ \\
\hline & 0.3861 & square mile $\left(\mathrm{mi}^{2}\right)$ \\
\hline liter $(\mathrm{L})$ & Volume & \\
cubic meter $\left(\mathrm{m}^{3}\right)$ & 0.2642 & gallon (gal) \\
milliliter $(\mathrm{mL})$ & 264.2 & gallon (gal) \\
microliter $(\mu \mathrm{L})$ & 0.0002642 & gallon (gal \\
& 0.0000002642 & gallon (gal) \\
\hline liter per second $(\mathrm{L} / \mathrm{s})$ & Flow rate & \\
\hline & 15.85 & gallon per minute $(\mathrm{gal} / \mathrm{min})$ \\
\hline gram $(\mathrm{g})$ & Mass & \\
microgram $(\mu \mathrm{g})$ & 0.03527 & ounce, avoirdupois $(\mathrm{oz})$ \\
kilogram $(\mathrm{kg})$ & 0.00000003527 & ounce, avoirdupois $(\mathrm{oz})$ \\
\hline & 2.205 & pound, avoirdupois $(\mathrm{lb})$ \\
\hline kilopascal $(\mathrm{kPa})$ & Pressure & \\
\hline & 0.1450 & pound per square inch $\left(\mathrm{lb} / \mathrm{in}^{2}\right)$ \\
\hline
\end{tabular}

Temperature in degrees Celsius $\left({ }^{\circ} \mathrm{C}\right)$ may be converted to degrees Fahrenheit $\left({ }^{\circ} \mathrm{F}\right)$ as follows:

$$
{ }^{\circ} \mathrm{F}=\left(1.8 x^{\circ} \mathrm{C}\right)+32
$$

Datums

Vertical coordinate information is referenced to the North American Vertical Datum of 1983 (NAVD 83)

Horizontal coordinate information is referenced to the North American Datum of 1983 (NAD 83)

Altitude, as used in this report, refers to distance above the vertical datum.

Specific conductance is given in microsiemens per centimeter at 25 degrees Celsius $(\mu \mathrm{S} / \mathrm{cm}$ at $\left.25^{\circ} \mathrm{C}\right)$.

Concentrations of chemical constituents in water are given either in milligrams per liter (mg/L) or micrograms per liter ( $\mu \mathrm{g} / \mathrm{L})$. 


$\begin{array}{ll}\text { AMPA } & \text { aminomethylphosphonic acid } \\ \text { ARMI } & \text { Amphibian Research and Monitoring Initiative } \\ \text { ASE } & \text { Accelerated Solvent Extractor } \\ \text { Bd } & \text { Batrachochytrium dendrobatidis } \\ \text { CDPR } & \text { California Department of Pesticide Regulation } \\ \text { DCM } & \text { dichloromethane } \\ \text { DOC } & \text { dissolved organic carbon } \\ \text { EI } & \text { electron ionization } \\ \text { GC-ITMS } & \text { gas chromatography/ion trap mass spectrometry } \\ \text { GPC/HPLC } & \text { gel permeation/high performance liquid chromatography system } \\ \text { HCI } & \text { hydrochloric acid } \\ \text { KNP } & \text { potassium hydrogen phthalate } \\ \text { LC/MS/MS } & \text { liquid chromatography/tandem mass spectrometry } \\ \text { MDL } & \text { method detection limits } \\ \text { MRM } & \text { multiple reaction monitoring } \\ \text { OGRL } & \text { USGS Organic Geochemisry Research Laboratory } \\ \text { PAH } & \text { polycyclic aromatic hydrocarbon } \\ \text { RMEML } & \text { USGS Reston Molecular and Environmental Microbiology Laboratory } \\ \text { SIM } & \text { selective ion monitoring mode } \\ \text { SIS } & \text { selective ion storage } \\ \text { SPE } & \text { solid-phase extraction } \\ \text { SRM } & \text { standard reference material } \\ \text { OA/OC } & \text { quality assurance/quality control } \\ \text { Toxics } & \text { USGS Toxics Substances Hydrology Program } \\ \text { USEPA } & \text { U.S. Environmental Protection Agency } \\ & \end{array}$


viii

This page intentionally left blank. 


\title{
Occurrence of Pesticides in Water and Sediment Collected from Amphibian Habitats Located Throughout the United States, 2009-10
}

\author{
By Kelly L. Smalling, James L. Orlando, Daniel Calhoun, William A. Battaglin, and Kathryn M. Kuivila
}

\begin{abstract}
Water and bed-sediment samples were collected by the U.S. Geological Survey (USGS) in 2009 and 2010 from 11 sites within California and 18 sites total in Colorado, Georgia, Idaho, Louisiana, Maine, and Oregon, and were analyzed for a suite of pesticides by the USGS. Water samples and bed-sediment samples were collected from perennial or seasonal ponds located in amphibian habitats in conjunction with research conducted by the USGS Amphibian Research and Monitoring Initiative and the USGS Toxic Substances Hydrology Program. Sites selected for this study in three of the states (California, Colorado, and Orgeon) have no direct pesticide application and are considered undeveloped and remote. Sites selected in Georgia, Idaho, Louisiana, and Maine were in close proximity to either agricultural or suburban areas. Water and sediment samples were collected once in 2009 during amphibian breeding seasons. In 2010, water samples were collected twice. The first sampling event coincided with the beginning of the frog breeding season for the species of interest, and the second event occurred 10-12 weeks later when pesticides were being applied to the surrounding areas. Additionally, water was collected during each sampling event to measure dissolved organic carbon, nutrients, and the fungus, Batrachochytrium dendrobatidis, which has been linked to amphibian declines worldwide. Bed-sediment samples were collected once during the beginning of the frog breeding season, when the amphibians are thought to be most at risk to pesticides. Results of this study are reported for the following two geographic scales: (1) for a national scale, by using data from the 29 sites that were sampled from seven states, and (2) for California, by using data from the 11 sampled sites in that state.

Water samples were analyzed for 96 pesticides by using gas chromatography/mass spectrometry. A total of 24 pesticides were detected in one or more of the 54 water samples, including 7 fungicides, 10 herbicides, 4 insecticides, 1 synergist, and 2 pesticide degradates. On a national scale, aminomethylphosphonic acid (AMPA), the primary degradate
\end{abstract}

of the herbicide glyphosate, which is the active ingredient in Roundup ${ }^{\circledR}$, was the most frequently detected pesticide in water (16 of 54 samples) followed by glyphosate ( 8 of 54 samples). The maximum number of pesticides observed at a single site was nine compounds in a water sample from a site in Louisiana. The maximum concentration of a pesticide or degradate observed in water was 2,880 nanograms per liter of clomazone (a herbicide) at a site in Louisiana. In California, a total of eight pesticides were detected among all of the low and high elevation sites; AMPA was the most frequently detected pesticide, but glyphosate was detected at the highest concentrations (1.1 micrograms per liter).

Bed-sediment samples were analyzed for 94 pesticides by using accelerated solvent extraction, gel permeation chromatography for sulfur removal, and carbon/alumina stacked solid-phase extraction cartridges to remove interfering sediment matrices. In bed sediment, 22 pesticides were detected in one or more of the samples, including 9 fungicides, 3 pyrethroid insecticides, $p, p$ '-dichlorodiphenyltrichloroethane ( $p, p^{\prime}$-DDT) and its major degradates, as well as several herbicides. Pyraclostrobin, a strobilurin fungicide, and bifenthrin, a pyrethroid insecticide, were detected most frequently. Maximum pesticide concentrations ranged from less than their respective method detection limits to 1,380 micrograms per kilogram (tebuconazole in California). The number of pesticides detected in samples from each site ranged from zero to six compounds. The sites with the greatest number of pesticides were in Maine and Oregon with six pesticides detected in one sample from each state, followed by Georgia with four pesticides in one sample. For California, a total of 10 pesticides were detected among all sites, and 4 pesticides were detected at both low and high elevation sites; tebuconazole and pyraclostrobin were the two most frequently detected pesticides in California. For the other six selected states, the most frequently detected pesticides in bed sediment were pyraclostrobin (detected in 17 of 42 samples), bifenthrin (detected in 14 of 42 samples), and tebuconazole (detected in 10 of 42 samples). 
The fungus, Batrachochytrium dendrobatidis (Bd), was detected in water samples in sites from four of the seven states during 2009 and 2010, and the number of zoospore equivalents per liter of water in samples where Bd was detected ranged from 1.6 to 343 . Bd was not detected in water samples from sites in Georgia, Louisiana, and Oregon.

\section{Introduction}

Amphibian populations are in decline worldwide (Lannoom, 2005; Mann, 2009). Most notably, studies in the Sierra Nevada Mountains of California have documented a significant decline in native amphibian populations over the last several decades (Fellers and Drost, 1993; Drost and Fellers, 1996; Davidson and others 2001; Fellers and others, 2004). Habitat loss, predation, disease (particularly the introduction of the fungus, Batrachochytrium dendrobatidis), and pollution, including pesticides, are factors thought to be involved in this decadal decline of amphibians (Fellers and others, 2004; and Mann, 2009). Agricultural chemicals acting singly or in combination with other stressors are receiving increasing attention as a potential cause of amphibian population declines (Relyea and Mills, 2001). Surveys of natural populations have shown correlations between population declines and proximity to agricultural lands (Mann, 2009). Moreover, the occurrence of malformed amphibians has been reported in agricultural areas where pesticides and fertilizers are applied extensively (Ouellet and others, 1997; Taylor and others, 2005). At high elevation sites (greater than 6,000 feet), including the Sierra Nevada, there is an increasing line of evidence supporting the hypothesis that atmospheric transport of pesticides to high elevation areas downwind of agricultural areas could be contributing to this decline (Fellers and others, 2004; Sparling and Fellers, 2007; Bradford and others, 2011).

Although the occurrence of a few pesticides (for example, atrazine and organophosphate insecticides) has been studied extensively in amphibian habitats, little is known about the exposure and potential effects on amphibian health of many of the newly registered and currently applied pesticides (Mann and others, 2009). In California, studies have focused primarily on the effects of organophosphate insecticides (chlorpyrifos, diazinon, malathion) and their metabolites on the yellow-legged frog (Sparling and Fellers, 2007; Bradford and others, 2011). Some formulations of glyphosate have been shown to be highly toxic to amphibians; however, this generally has been attributed to the surfactant present in these formulations rather than glyphosate itself (Howe and others, 2004; Relyea, 2005). A few studies have highlighted the effects of cypermethrin (a pyrethroid insecticide) on larval development of amphibians (Greulich and Pflugmacher, 2003; 2004), and a recent study described the effects of several fungicide formulations on tadpoles and juvenile frogs. At environmentally relevant concentrations, Headline $^{\circledR}$, containing pyraclostrobin (strobilurin fungicide), caused 100 percent mortality to tadpoles (Bufo cognatus) after 72 hours of exposure (Belden and others, 2010).

The chytrid fungus, Batrachochytrium dendrobatidis (Bd), has been linked to amphibian declines worldwide (Daszak and others, 2003; Lips and others, 2008; Vredenburg and others, 2010). The widespread occurrence of $\mathrm{Bd}$ on amphibians in the United States is becoming well documented (Longcore and others, 2007; Pearl and others, 2007; Woodhams and others, 2008). Bd infects susceptible amphibians directly and can cause acute or chronic effects. Amphibians produce antimicrobial peptides as a defense mechanism against disease, particularly Bd (Rollins-Smith, 2009). It has been hypothesized that stressors, such as pollution, can cause reduction of antimicrobial peptide production, resulting in amphibians becoming more susceptible to Bd and other diseases. Currently, little is known about how water quality affects the occurrence of $\mathrm{Bd}$ on amphibians or in waters that serve as amphibian habitats in the United States. One recent study has shown that exposure to several agricultural chemicals likely can lead to a higher susceptibility rate of $\mathrm{Bd}$ infections in amphibians (Davidson and others, 2001).

Pesticide use is constantly changing, and ongoing studies by USGS scientists and others are documenting the widespread occurrence of newer fungicides and pyrethroids as well as a variety of other currently used pesticides throughout the Nation's surface waters and sediments.

\section{Purpose and Scope}

This report describes the methods and procedures used to determine pesticide concentrations in 55 water and 40 sediment samples collected from 11 amphibian habitat sites in California and in 6 other states across the NationColorado, Georgia, Idaho, Louisiana, Maine, and Oregon - in 2009 and 2010. Water samples were analyzed for a suite of 96 pesticides, and sediment samples were analyzed for a suite of 94 pesticides. Water samples collected from 90 percent of the sites were also analyzed for the fungus, Batrachochytrium dendrobatidis. Concentrations of pesticides in water and bed sediment, Batrachochytrium dendrobatidis, dissolved organic carbon, nutrients, and particulate organic carbon in bed sediment are presented. This report supports efforts by other USGS Amphibian Research and Monitoring Initiative (ARMI) scientists and will allow them to use the data to interpret statespecific results in an effort to begin to understand the potential effects of pesticides on amphibian populations nationwide. 


\section{Study Design}

The primary objective of this study was to investigate the potential roles of environmental contaminants, particularly pesticides, as stressors contributing to the amphibian population decline. The study was designed to address the question of effects of current-use pesticides on amphibians, with the initial focus on the potential exposure and accumulation in pond breeding frogs across the Nation. To answer the occurrence question, water and bed-sediment samples were collected from amphibian habitats in selected states throughout the U.S. and analyzed for a suite of current-use pesticides and degradates. In 2009, field sampling focused primarily on frog habitats in California, where previous studies had linked pesticides with decreased frog populations, with a few additional samples from sites in Colorado, Maine, and Oregon. In 2010, the scope expanded to include more sites outside of California in Colorado, Georgia, Idaho, Louisiana, and Oregon. Sites were selected for this study on the basis of several criteria: (1) they all contained actively breeding native amphibian populations, (2) they were of interest to collaborating ARMI herpetologists, and (3) they were in proximity to agricultural or urban areas where pesticides were being applied. Watershed boundaries were delineated for sites in California to investigate land-use patterns and potential pesticide use within these boundaries. Elevations were determined by referencing the appropriate topographic map for each site. The U.S. Environmental Protection Agency (USEPA) Level III Ecoregions (Omernik, 1987) also were determined for each of the sampling sites. The results of this study will be used to focus future efforts by the USGS ARMI and the USGS Toxics Substances Hydrology Program (Toxics) to better understand the effects of pesticides and other environmental contaminants on amphibians and the ecosystems that they inhabit.

\section{Timing of Sample Collection}

Samples were collected in 2009 between May and October and coincided with amphibian breeding season in all seven states. In 2009, samples for pesticides, Bd, and nutrients were only collected once. Sample collection in each state varied on the basis of amphibian species of interest and their respective breeding or active season. In 2010, water for pesticides, nutrients, and Bd was collected twice from each site. Similar to 2009, sampling was initiated by amphibian breeding season in the early spring, and samples were collected between February and July depending on region. Surface water also was collected a second time, 10-12 weeks following the first event, when pesticide application is at its peak. Bed-sediment samples were collected only once during the first sampling event in the early spring and summer.

\section{Descriptions of Watersheds and Sampling Sites throughout the United States}

\section{California}

A total of 11 sites were sampled in California in north-south and east-west transects across the state from sea level to nearly 10,000 feet (ft) in elevation in the Sierra Nevada. Locations ranged west to east from Point Reyes National Seashore and the California Coast Range in the west to the Tioga Pass in Yosemite National Park in the Sierra Nevada to the east, and from Lassen Peak (Lassen Volcanic National Park) in the north to Sequoia National Park in the south (fig. 1). Sites were located in multiple ecoregions (Southern and Central California Chaparral and Oak Woodlands, Central California Valley, and Sierra Nevada) representing different habitat types. Samples were collected from seasonal or perennial ponds (table 1) ranging in size from a few feet to hundreds of feet in diameter. Generally these ponds have relatively small contributing watershed areas (16-1,275 acres).

\section{Low-Elevation Coastal and Sierra Nevada Foothill Sites}

Low-elevation sites consisted of one site in Point Reyes National Seashore (Pond near Olema), one site in the foothills of the Coast Range (Brushy Pond near Livermore), and two sites in the Sierra Nevada foothills (Pond next to Jordan Creek near Groveland; and, Pond near Woodward Reservoir near Oakdale; fig. 1). Elevations of these sites ranged from 110 to 2,650 ft above sea level (table 1) and their respective watersheds ranged from 15.6 to 1,275 acres in size. Landcover within these watersheds was primarily grasslands and scrub (Homer and others, 2007). The sites generally were located within 10 miles of urban areas or agriculture, although these land uses did not occur directly within the watersheds.

\section{High-Elevation Sierra Nevada Sites}

Seven high-elevation sites were sampled in the Sierra Nevada (fig. 1). Sites ranged from near Lassen Peak in the north to Sequoia National Park in the south. Elevations, shown in table 1, ranged from 6,740 to 9,960 feet above sea level. Watersheds were small (12.4-394.6 acres), and landcover for all watersheds was evergreen forest predominantly. With the exception of one site (Pond at Paige Meadow near Tahoe City), all sites were isolated from urban areas and agriculture. 


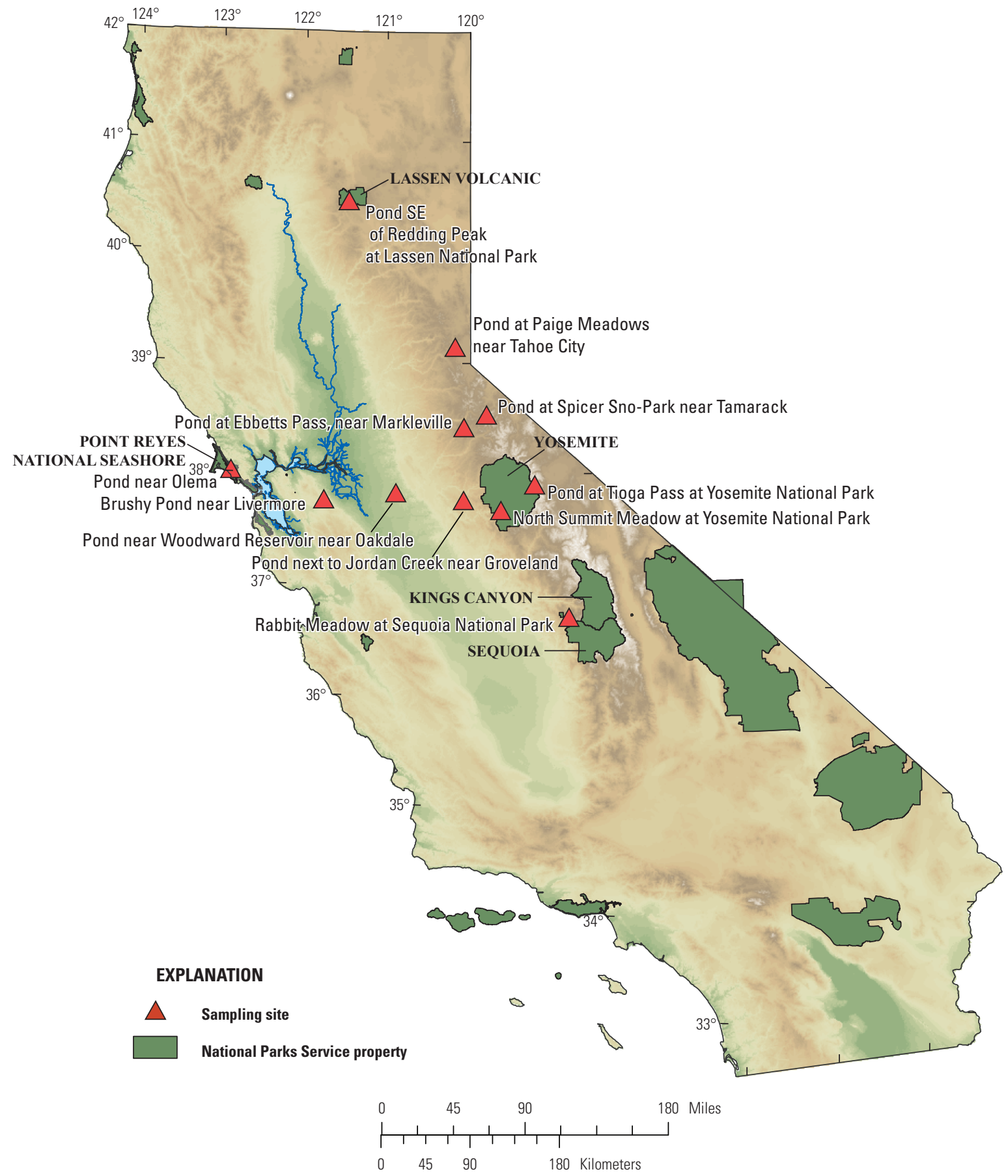

Figure 1. Location of sites sampled in California, 2009-10. 


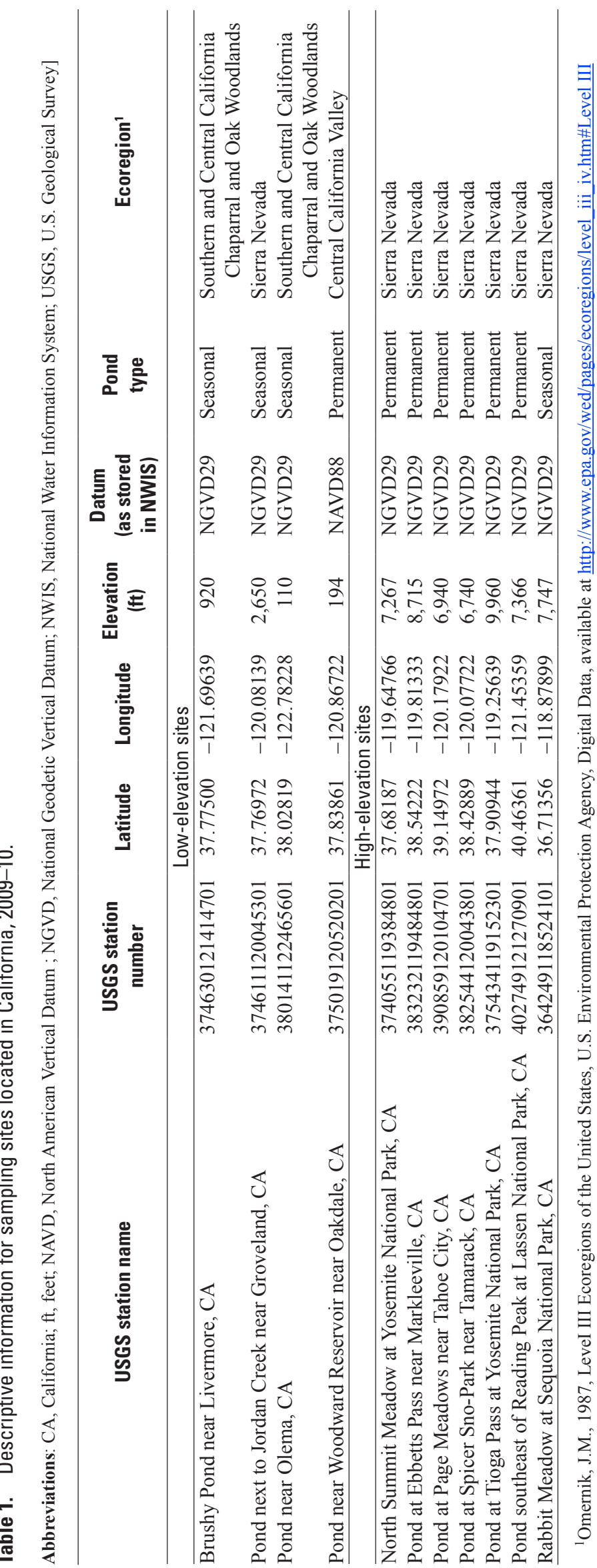




\section{Colorado}

Five sites were sampled in the San Luis Valley in South Central Colorado (fig. 2; table 2). Sites ranged in elevation from 7,519 to 7,609 $\mathrm{ft}$ above sea level and are in the Arizona/ New Mexico Plateau ecoregion, which represents high semiarid grasslands (table 2). Sites generally were wetlands receiving water inputs from a combination of precipitation, groundwater, streams, canals, and wells. All sites were located approximately 10-20 mi to the east or south-east of an area of intensive irrigated agriculture that produces predominantly potatoes, barley, wheat, and alfalfa (U.S. Department of Agriculture, 2010). The North Pond and Sand Creek sites are on the west side of Great Sand Dunes National Park on lands managed by the Nature Conservancy (historic Medano
Ranch). The area is not generally open to the public and is primarily used for bison grazing. Groundwater, intermittent streams, and precipitation are the primary sources of water to these sites. The Cochran Lane and Stanley Road sites are in the Rio Grande State Wildlife Area. Both sites are adjacent to the Rio Grande River. At Stanley Road, the primary source of water is an agricultural drain, whereas at Cochran Lane, water comes from a mixture of sources, including groundwater, precipitation, a canal, and an agricultural drain. The Mumm Lateral site is in the Alamosa National Wildlife Refuge. The primary source of water at this site is the Mumm artesian well, which is the largest artesian well in the San Luis Valley and can produce more than 2,800 gallons per minute (U.S. Fish and Wildlife Service, 2003). Samples from these sites were collected between June and August in both 2009 and 2010.

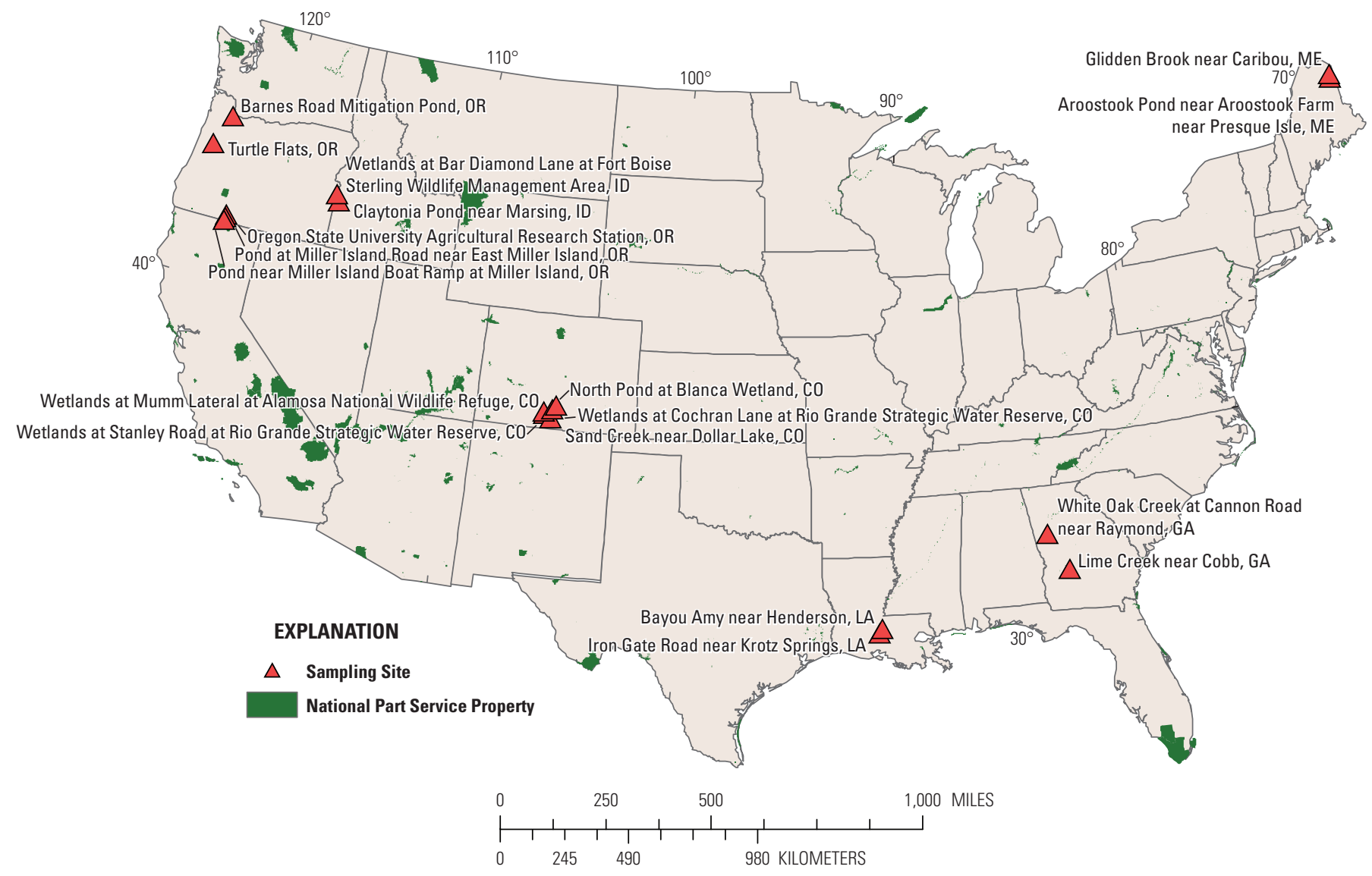

Figure 2. Location of sampling sites in Colorado, Georgia, Idaho, Louisiana, Maine, and Oregon, 2009-10. 


\section{Georgia}

Two lotic stream sites were sampled in Georgia. White Oak Creek is located in the Piedmont province of the state, and Lime Creek is located in the Upper Coastal Plain province (fig. 2; table 2); both streams are tributaries to the Flint River. The sampled sites are on private land and were selected on the basis of the predominant land use within the contributing watersheds. White Oak Creek drains a rural to suburban 47-square mile $\left(\mathrm{mi}^{2}\right)$ watershed that is in Coweta County and in the Metropolitan Statistical Area of Atlanta, Ga. The city of Newnan, Ga. is in the headwaters of the watershed, and two 18-hole golf courses are upstream of the sampled site. Land use in the watershed is predominately forest and pasture; however, 26 percent of the basin is developed (Hughes and Moon, 2009). The Lime Creek sampling site is in Sumter County, and the city of Americus is in the headwaters of the 61-square mile watershed. Land use surrounding these sites is predominately row-crop agriculture with cotton, soy beans, and peanuts being the primary crops cultivated (Hippe and others, 1995). Both streams have extensive riparian flood plains near the sampled locations that provided ample amphibian habitat. Samples were collected twice from these sites in both June and August of 2010.

\section{Idaho}

Two sites were sampled in the Boise-Snake River Valley in Southeastern Idaho. These sites are at approximately 2,200 ft above sea level and are in the Snake River Plain ecoregion, representing mostly gently sloping lands with large areas of irrigated agriculture (fig. 2; table 2). The Wetlands at Bar Diamond Lane site is in the Fort Boise Wildlife Management Area along Sand Hollow Creek. This site has a drainage area of approximately $100 \mathrm{mi}^{2}$, which is primarily irrigated agricultural land. The Claytonia Pond Site is an old gravel pit with a small (less than $1 \mathrm{mi}^{2}$ ) natural drainage area that also receives water from the C-Line Canal. The area surrounding the pond is primarily irrigated agricultural land. Samples were collected from the two sites in May and June of 2010 .

\section{Louisiana}

Two sites were sampled in southeastern Louisiana. These sites are less than $20 \mathrm{ft}$ above sea level and are in the Mississippi Alluvial Plain ecoregion, which is primarily forested lands and low lying agricultural areas (fig. 2; table 2). The Bayou Amy near Henderson, La., site is a canal that drains into Dauterive Lake approximately $30 \mathrm{mi}$ south of the collection site. The canal is in close proximity to agricultural lands, including rice fields. The Iron Gate Road near Krotz Springs, La., site is a 20 by 30 -meter L-shaped pond located near two small clearings with a small outlet running southwest directly north of Iron Gate Road . The area surrounding the pond is predominantly forested. Samples were collected from Bayou Amy near Henderson, La., in April and September 2010, and samples were collected from Iron Gate Road near Krotz Springs, La., in June 2010.

\section{Maine}

Two sites were sampled in the Aroostook Plateau in northeastern Maine. These sites are at approximately $500 \mathrm{ft}$ above sea level and are in the Acadian Plains and Hills ecoregion, representing mostly forested land with abundant lakes (fig. 2; table 2). The Glidden Brook site has a drainage area of approximately $4 \mathrm{mi}^{2}$ of mixed forest and agricultural land. The watershed area for Aroostook Pond site is on the University of Maine Aroostook Research Farm. Sites were selected on the basis of their close proximity to areas of moderate agricultural activity in each watershed. Both sites are less than $2 \mathrm{mi}$ from fields that produce mostly potatoes and other vegetables in their respective watersheds. Samples were collected from both sites in July 2009.

\section{Oregon}

Five sites were sampled in various watersheds in both the Willamette Valley and Klamath Basin in Oregon. The two sites in the Willamette Valley are at approximately $200 \mathrm{ft}$ in altitude and are in the Willamette Valley ecosystem, representing wet lowlands (fig. 2; table 2). The Barnes Mitigation Pond site is a permanent wetland complex in a suburban setting adjacent to Johnson Creek. The Turtle Flats site is a temporary man-made wetland on the Findley National Wildlife Refuge maintained with water occasionally pumped by the refuge from Muddy Creek. The three sites in the Klamath Basin are at approximately $4,100 \mathrm{ft}$ in altitude and are in the Eastern Cascades Slopes and Foothills ecosystem, which is primarily high desert (table 2). The Oregon State University (OSU) Agricultural Research Station site is on a canal on Extension Service property, which focuses on potato production. The Pond at Miller Island Road and Pond at Miller Island Boat Ramp sites are located on the east and west sides, respectively, of the Klamath Wildlife Area. This area is managed by the Oregon Department of Fish and Wildlife primarily for migratory water birds (for example, ducks, geese, pelicans, shorebirds). The eastern site is along Highway 97 and the western site is adjacent to the Klamath River. There is irrigated agricultural land within the Wildlife Area on Miller Island and in the surrounding area. In 2009, samples were collected in September and October from the Barnes Mitigation Pond site, the OSU Agricultural Research Station site and the Turtle Flats site. Samples were collected from the Pond at Miller Island Road and Pond at Miller Island Boat Ramp sites in May and September of 2010. 


\section{Pesticide Use}

Since 1990, the California Department of Pesticide Regulation (CDPR) has followed a reporting system that requires pesticide applicators to provide detailed information on pesticide use. Pesticide-use data reported by agricultural applicators contains detailed information, including the date, time, crop, and location of application to the section level, as referenced by the public land survey system, as well as the amount and type of pesticide product applied. Pesticides applied by licensed applicators in urban settings (primarily for landscape maintenance and structural pest control) are reported with less detail, supplying only the month and county of the pesticide product and amount applied. The CDPR reporting system does not contain information on pesticide applications made by homeowners using products purchased at retail stores. The CDPR system is comprehensive, and these data are extremely valuable in assessing trends in pesticide use, changes in application patterns, and potential for environmental contamination. Pesticide application data for the 2009 calendar year shown in this report were the latest data contained in the CDPR database at the time of data compilation for this study.

On the basis of information in the CDPR database, pesticides were applied within approximately $1 \mathrm{mi}$ of one low-elevation site in 2009 (Pond near Woodward Reservoir near Oakdale, Calif.). Near the Woodward site, 36 different pesticides were applied to 6 crops (alfalfa, almonds, corn, oats, pasture, and walnuts). Total pesticide use near the Woodward site amounted to over 5,000 pounds (lbs) of active ingredients. Excluding petroleum and mineral oils, glyphosate was the most heavily used pesticide in the area surrounding this site in 2009 (California Department of Pesticide Regulation, 2010).

Although the CDPR database does not contain locationspecific information on urban pesticide application or any data on the home use of pesticides, the remote locations of the California sites makes it unlikely that urban pesticide use takes place within or in close proximity to the sampling sites.

Detailed pesticide-application data for the sites outside California are not available. National county-level data are not currently available and the most recent national pesticide-use data are from 2002.

\section{Procedures and Methods}

\section{Sampling Methods}

Sampling of water and bed-sediment for pesticides was conducted following the same procedures at all sites. Water samples were collected by immersing a precleaned 4-liter (L) amber glass bottle once at each site. Each bottle was filled at a depth of not less than 0.1-meter (m) below the water surface. At the time of sample collection, basic water-quality parameters, including temperature, specific conductance, $\mathrm{pH}$, dissolved oxygen concentration, and turbidity, were measured by using a multi-parameter meter (YSI model 6920V2). Water also was collected from each site for measurements of major ions and nutrients, including total nitrogen, phosphorus, orthophosphorus, and nitrate/nitrite, and was shipped to the USGS National Water Quality Laboratory for analysis.

Bed-sediment samples were collected from areas of active sediment deposition near where the water samples were collected. Samples were collected by using a stainless-steel scoop to sample the top 2 centimeters $(\mathrm{cm})$ of bed material from multiple points within approximately a 1-square-meter area. Sediment was passed through a 4-millimeter mesh sieve into a pre-cleaned stainless steel bowl, homogenized, and transferred to $500-\mathrm{mL}$ ) baked glass jars. Samples were transported on ice to the USGS Organic Chemistry Research Laboratory in Sacramento, California, where they were stored frozen until analysis.

Water for Bd analysis was collected from three separate locations from a single site by using a $60-\mathrm{mL}$ syringe. Approximately 100-300 mL (depending on turbidity) of water from each location was filtered through a 0.2 -micrometer $(\mu \mathrm{m})$ Sterivex capsule filter until the filter reached capacity. All sample volumes from each site were recorded on field data sheets. After sample collection, $50 \mathrm{~mL}$ of phosphate buffer solution was pushed through the filter, and the capsule was pumped dry. The capsule was sealed with a sterile clay sealant, and $0.9 \mathrm{~mL}$ of lysis buffer solution was added to the filter to preserve the DNA. The three capsules collected per site were placed directly on ice and shipped to the USGS Reston Molecular and Environmental Microbiology Laboratory (RMEML) in Reston, Virginia, for processing.

\section{Analytical Methods}

\section{Sample Preparation for Dissolved Pesticides}

All water samples were filtered by using $0.7-\mu \mathrm{m}$ glass fiber filters (Grade GF/F; Whatman, Piscataway, New Jersey) to remove suspended material. Filtered water samples were analyzed for a suite of 94 pesticides by extracting $1 \mathrm{~L}$ of sample water onto Oasis HLB solid-phase extraction (SPE) cartridges ( 6 cubic centimeters, $500 \mathrm{mg}, 60 \mu \mathrm{m}$, Waters Corporation, Milford, Massachusetts). All samples were spiked with ${ }^{13} \mathrm{C}_{3}$-atrazine, and diazinon diethyl- $\mathrm{d}_{10}$ (Cambridge Isotopes, Andover, Mass.) as recovery surrogates. Following extraction, the SPE cartridges were dried, eluted with $12 \mathrm{~mL}$ of ethyl acetate, and the eluents were reduced under nitrogen. After extraction, approximately 1 gram (g) of sodium sulfate $\left(\mathrm{Na}_{2} \mathrm{SO}_{4}\right)$ was added to the sample bottles to remove any residual water, and the bottles were rinsed three times with dichloromethane (DCM). The bottle rinses were reduced in volume to $1 \mathrm{~mL}$ under nitrogen and combined with the ethyl acetate fractions. Each entire sample (bottle 
rinse plus SPE elution) was reduced to a final volume of 200 microliters $(\mu \mathrm{L})$ for analysis. Deuterated polycyclic aromatic hydrocarbon (PAH) compounds were used as internal standards and included acenaphthene- $\mathrm{d}_{10}$ and pyrene- $\mathrm{d}_{10}$. All sample extracts were analyzed by gas chromatography/ion trap mass spectrometry (GC-ITMS). Additional details are given in Hladik and others (2008).

\section{Sample Preparation for Sediment-Associated Pesticides}

Sediment samples were extracted for 94 pesticides on the basis of methods described by Smalling and others (2005) and Smalling and Kuivila (2008). Prior to extraction, sediment samples were spiked with trifluralin- $\mathrm{d}_{10}$, ring- ${ }^{13} \mathrm{C}-p, p$ '-DDE and phenoxy- ${ }^{13} \mathrm{C}$-cis-permethrin (Cambridge Isotopes, Andover, Mass.) as recovery surrogates. Wet sediments were homogenized with $\mathrm{Na}_{2} \mathrm{SO}_{4}$ by using a solvent-rinsed mortar and pestle and extracted by pressurize liquid extraction by using a Dionex 200 (Sunnyvale, Calif.) Accelerated Solvent Extractor (ASE). Samples were extracted three times with DCM at $100^{\circ} \mathrm{C}$ and 1,500 pounds per square inch. Following extraction, sample extracts were dried over $\mathrm{Na}_{2} \mathrm{SO}_{4}$ and reduced to $0.5 \mathrm{~mL}$ by using a Turbovap II (Zymark Corporation, Hopkins, Mass.) rotary evaporator. Sulfur was removed by using a gel permeation/high performance liquid chromatography system (GPC/HPLC) with DCM as the carrier solvent. Samples were reduced to $0.5 \mathrm{~mL}$ again, split into two aliquots, and subjected to two different clean-up methods, depending on compounds of interest.

The first clean-up method included all compounds except the 33 fungicides. The interfering matrix was removed by passing the sample extract through two stacked solid-phase extraction (SPE) cartridges containing $500 \mathrm{mg}$ of nonporous, graphitized carbon (Restek Corporation, Bellefonte, Va.) and $500 \mathrm{mg}$ of alumina (Varian Inc., Palo Alto, Calif.) The cartridges were washed in tandem with $10 \mathrm{~mL}$ of DCM prior to sample extract addition. Compounds of interest were eluted off both SPE cartridges with $10 \mathrm{~mL}$ of DCM and collected as fraction 1 (F1). The carbon SPE was removed and the alumina SPE was eluted with $10 \mathrm{~mL}$ of ethyl acetate and $\operatorname{DCM}$ (50:50 volume-volume) and collected as fraction 2 (F2; Smalling and others, 2005). Both fractions were evaporated separately under a gentle stream of purified nitrogen gas (N-evap, Organomation Associates, Berlin, Mass.) to $0.2 \mathrm{~mL}$, and the deuterated PAH internal standard mixture was added.

The second clean-up method was designed for the 33 fungicides. The interfering matrix was removed by using a $200-\mathrm{mL}$ glass column $(400 \mathrm{~mm} / \mathrm{L} \times 10 \mathrm{~mm}$ inner diameter $)$ dry packed with 6 percent water (volume-weight deactivated Florisil (60-100 mesh chromatographic grade, ThermoFisher Scientific, Waltham, Mass., USA). The Florisil had been activated previously at $550^{\circ} \mathrm{C}$ in a muffle furnace for 16 hours. The compounds of interest were eluted with 20 $\mathrm{mL}$ of 20 percent DCM in hexane followed by $100 \mathrm{~mL}$ of 60 percent ethyl acetate in hexane collected in the same flask. Following Florisil clean-up and fractionation, both the extracts were reduced to approximately $0.2 \mathrm{~mL}$ under a gentle steam of $\mathrm{N}_{2}$, exchanged to ethyl acetate, and deuterated PAH internal standards were added prior to analysis. Additional details of the method are described in Smalling and Kuivila (2008).

\section{Instrument Calibration and Analysis for Pesticides}

Instruments were calibrated by using concentration standards that spanned the linear range of instrument response. Calibration curves were considered acceptable if the $\mathrm{R}^{2}$ for each individual compound was greater than 0.995 . The response of the instrument was monitored every 6-8 samples with mid-level check standards. The instruments were considered to be stable if the recovery of the check standards fell within the range of 80-115 percent of the nominal standard concentration. If environmental sample concentrations fell outside the linear range of the instrument, the samples were diluted appropriately and reanalyzed.

Water and sediment extracts ( $1 \mu \mathrm{L}$ injection volume) were analyzed for herbicides and insecticides on a Varian Saturn 2000 (Walnut Creek, Calif.) gas chromatograph/ion trap mass spectrometer (GC/IT-MS). Analyte separation on the gas chromatograph was achieved by using a $30 \mathrm{~m} \times 0.25-\mathrm{mm}$ inner diamter, $0.25 \mu \mathrm{m}$ DB-5ms fused silica column (Agilent Technologies, Folsom, Calif.) with helium as the carrier gas. The temperature of the splitless injector was held constant at $275^{\circ} \mathrm{C}$. The temperature program was $80^{\circ} \mathrm{C}$, hold 0.5 minutes (min); increase to $120^{\circ} \mathrm{C}$ at $10^{\circ} \mathrm{C} / \mathrm{min}$; increase to $200^{\circ} \mathrm{C}$ at $3^{\circ} \mathrm{C} / \mathrm{min}$, hold $5 \mathrm{~min}$; increase to $219^{\circ} \mathrm{C}$ at $3^{\circ} \mathrm{C} / \mathrm{min}$; and a final increase to $300^{\circ} \mathrm{C}$ at $10^{\circ} \mathrm{C} / \mathrm{min}$, hold $10 \mathrm{~min}$. The transfer line and ion trap temperatures were $280^{\circ} \mathrm{C}$ and $220^{\circ} \mathrm{C}$, respectively. The mass spectrometer was operated in electron ionization (EI) mode with an emission current of 15 microamps $(\mu \mathrm{A})$ and no offset, when run in full scan mode, and an emission current of $45 \mu \mathrm{A}$ with a multiplier offset of 300 volts, when using selective ion storage (SIS) mode. Data were collected in full scan and SIS modes. Complete details of the analytical method are described in LeBlanc and others (2004) and Smalling and Kuivila (2008).

Water and sediment sample extracts $(1 \mu \mathrm{L})$ were analyzed for fungicides on an Agilent 7890 gas chromatograph coupled to a 5975 (Folsom, Calif.) mass spectrometer operating in electron ionization mode (GC/EI-MS). Analyte separation was achieved by using a $30-\mathrm{m} \times 0.25$-mm inner diameter, $0.25 \mu \mathrm{m}$ DB-5ms fused silica column (Agilent Technologies, Folsom, Calif.) with helium as the carrier gas. The temperature of the splitless injector was held constant at $275^{\circ} \mathrm{C}$. The temperature program was $80^{\circ} \mathrm{C}$ (hold $0.5 \mathrm{~min}$ ), increase to $180^{\circ} \mathrm{C}$ at $10^{\circ} \mathrm{C} / \mathrm{min}$, increase to $220^{\circ} \mathrm{C}$ at $5^{\circ} \mathrm{C} / \mathrm{min}$ (hold $1 \mathrm{~min}$ ), increase to $280^{\circ} \mathrm{C}$ at $4^{\circ} \mathrm{C} / \mathrm{min}$ (hold $1 \mathrm{~min}$ ), and a final increase to $300^{\circ} \mathrm{C}$ at $10^{\circ} \mathrm{C} / \mathrm{min}$ (hold $10 \mathrm{~min}$ ). The transfer line, quadrupole, and source temperatures were $280^{\circ} \mathrm{C}, 150^{\circ} \mathrm{C}$, and $230^{\circ} \mathrm{C}$, respectively. Data for all fungicides were collected in selective ion monitoring mode (SIM) with each compound having one quantifier ion and 1-2 qualifier ions (Reilly and others, 2012). 


\section{Method Detection Limits for Pesticides}

Surface-water and sediment method-detection limits (MDLs) were validated in previous studies (Hladik and others, 2008; Smalling and Kuivila, 2008; Reilly and others, 2012) by using the procedure described in 40 CFR Part 136 Appendix B (U.S. Environmental Protection Agency, 1992). Water samples used to determine MDLs for insecticides and herbicides were collected in 2005 from the Sacramento River at Miller Park, and water samples for fungicide MDLs were collected in 2008 from the American River near the California State University, Sacramento, campus. Sediment samples for insecticides and herbicides were collected in 2004 from the Cache Creek inflow to the settling basin near Woodland (USGS site identification number 384340121434401). In 2011, fungicide MDLs were determined by using sediment collected from the Yolo Bypass near Woodland (USGS site identification number 11453000). The MDLs were calculated for each compound by using the following equation:

$$
M D L=S \times t(n-1,1-\alpha=0.99)
$$

where

$M D L$ is the method detection limit $(\mu \mathrm{g} / \mathrm{kg})$,

$S$ is the standard deviation of replicate samples, $n$ is the number of replicates, and

$t$ is the value of Student's t statistics at 6 degrees of freedom and 99 percent confidence level.

MDLs for pesticides, not including AMPA, glufosinate and glyphosate, in surface water ranged from 0.9 to 10.5 nanograms per liter (ng/L). Sediment MDLs for all pesticides measured ranged from 0.6 to 3.8 micrograms per kilogram $(\mu \mathrm{g} / \mathrm{kg}$; tables 3 and $\underline{4})$. Analytes can be identified at concentrations less than the MDL with lower confidence in the actual value; therefore, concentrations of compounds detected below the MDLs are reported as estimates.

\section{Glyphosate, AMPA, and Glufosinate Analysis}

Surface-water samples (125 mL) also were analyzed for glyphosate and its two major degradates, aminomethylphosphonic acid (AMPA) and glufosinate, by the USGS Organic Geochemisry Research Laboratory (OGRL) in Lawrence, Kansas. Filtered water samples were stored at $4^{\circ} \mathrm{C}$ then derivatized within 5 days after collection by using a 5-percent borate buffer to adjust the $\mathrm{pH}$ to 9.0 , followed by the addition of 2.5 millimolar $(\mathrm{mM})$ 9-fluorenylmethylchloroformate in acetonitrile. Derivatization was carried out in the dark in a water bath at $40^{\circ} \mathrm{C}$ for approximately 24 hours. Following derivatization, the samples were extracted onto SPE cartridges, and the SPE cartridges were rinsed with $500 \mu \mathrm{L}$ of deionized water.

All sample extracts for AMPA, glufosinate, and glyphosate were analyzed by liquid chromatography/tandem mass spectrometry (LC/MS/MS) with electrospray ionization in negative-ion mode by using multiple reaction monitoring (MRM). MDLs for AMPA, glyphosate, and glufosinate in surface water were $0.02 \mu \mathrm{g} / \mathrm{L}$ (table 3). Complete details of the method are described in Meyer and others (2009).

\section{Dissolved Organic Carbon}

Filtered water samples were analyzed for dissolved organic carbon (DOC) by high-temperature catalytic combustion by using a Shimadzu TOC-V $\mathrm{V}_{\mathrm{CNS}}$ total organic carbon analyzer (Shimadzu Scientific Instruments, Columbia, Maryland) according to a modified version of USEPA Method 415.3 (Potter and Wimsatt, 2005). The instrument was calibrated by using potassium hydrogen phthalate (KNP) standards prepared in organic-free water with concentrations ranging from 0.0 to $4.0 \mathrm{mg} / \mathrm{L}$. All standards, blanks, and samples were acidified prior to analysis by using approximately four drops of concentrated sulfuric acid to lower the $\mathrm{pH}$ to approximately 1.9. The accuracy and precision of the measurements were within 5 percent as indicated by internal standards (KNP and caffeine), laboratory replicates, and matrix spikes (Bird and others, 2003; Potter and Wimsatt, 2005).

\section{Nutrients}

Major ions and nutrients, including total nitrogen, total phosphorous, orthophosphate, and nitrate/nitrite, were analyzed in filtered and unfiltered water samples by the National Water Quality Laboratory by using approved methods outlined in Fishman (1993). Method detection limits for total nitrogen, total phoshorous, orthophosphate as phosphorus, and nitrate/nitrite as nitrogen were 0.05, 0.003, 0.004 , and $0.008 \mathrm{mg} / \mathrm{L}$, respectively.

\section{Batrachochytrium dendroibatidis Analysis}

DNA was extracted from capsule filters by using a Puregene kit for tissue (Gentra Systems, Valencia, Calif.) and amplified and analyzed by quantitative polymerase chain reaction (qPCR) technique following methods established by Kirshtein and others (2007). Capsule filters were incubated at $55^{\circ} \mathrm{C}$ for $60 \mathrm{~min}$ under continual rotation to extract DNA. The lysis mixture was removed from the capsule filter and stored at $-20^{\circ} \mathrm{C}$ prior to analysis. Purified DNA was analyzed by using qPCR on a MX4000 QPCR system (Statagene ${ }^{\circledR}$, La Jolla, Calif.) that used a Taq polymerase assay with a TaqMan MGB probe and cycling parameters as follows: one 9-minute step at $95^{\circ} \mathrm{C}$, then 50 cycles at $94^{\circ} \mathrm{C}$ for 30 seconds, and finally $60^{\circ} \mathrm{C}$ for 1 minute. A standard curve was constructed from a dilution series of Bd zoospore extracts of a known concentration and data were expressed as zoospore equivalents per liter (zoospore equiv/L). 
Table 3. Method detection limits for insecticides and herbicides in water and sediment.

[Concentrations in water are expressed in nanograms per liter (ng/L) unless otherwise noted; concentrations in sediment are expressed in micrograms per kilogram $(\mu \mathrm{g} / \mathrm{kg})$. Abbreviations: AMPA, aminomethylphosphonic acid; EPTC, S-Ethyl dipropylthiocarbamate; NA, not applicable]

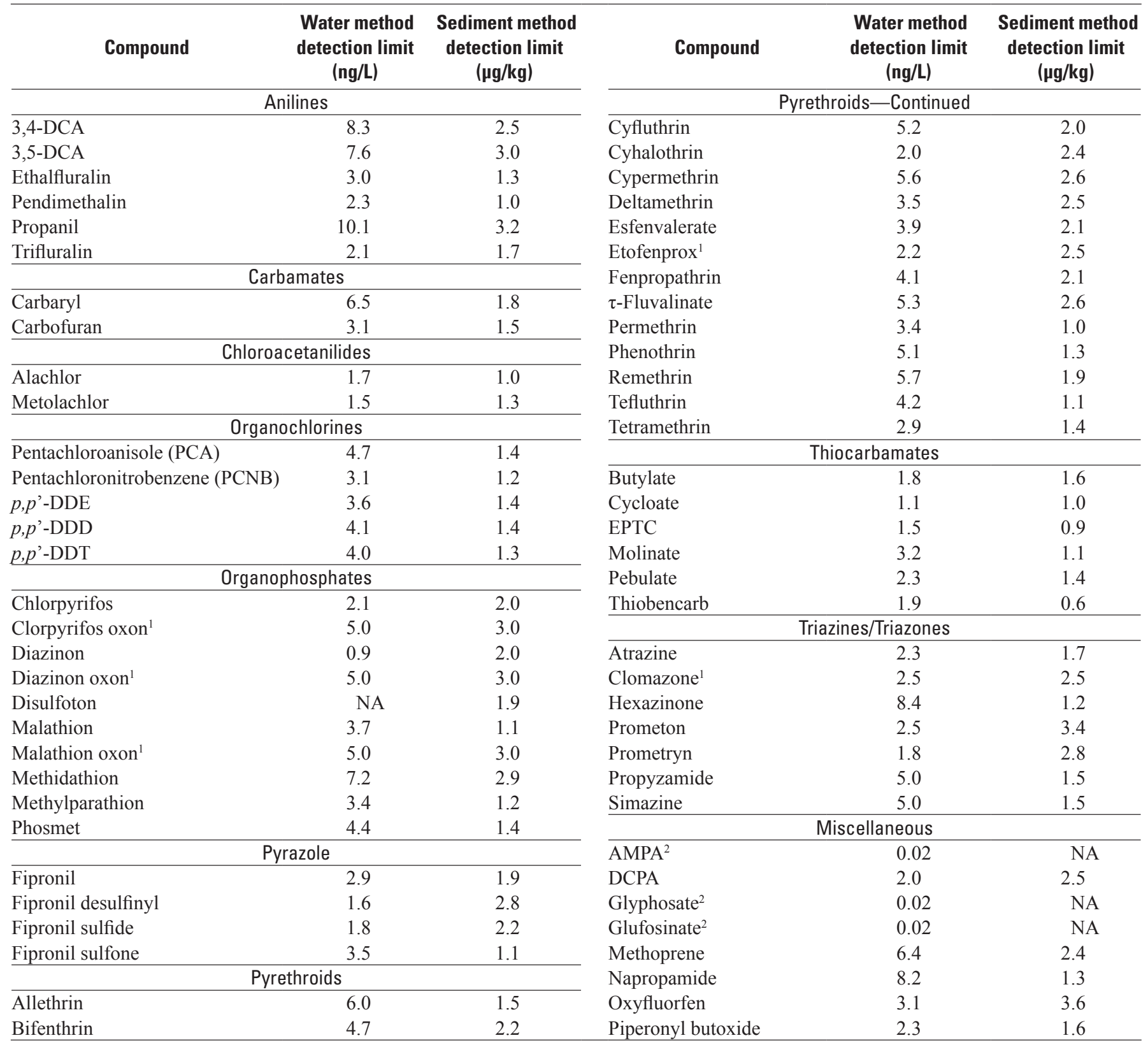

${ }^{1}$ Method detection limit not available; used a limit of detection.

${ }^{2}$ Concentrations in micrograms per liter. 
Table 4. Method detection limits for fungicides in water and sediment.

[Concentrations in water are expressed in nanograms per liter (ng/L); concentrations in sediment are expressed in micrograms per kilogram $(\mu \mathrm{g} / \mathrm{kg})$. Abbreviations: NA, not applicable]

\begin{tabular}{|c|c|c|}
\hline Compound & $\begin{array}{l}\text { Water method } \\
\text { detection limit } \\
\text { (ng/L) }\end{array}$ & $\begin{array}{c}\text { Sediment method } \\
\text { detection limit } \\
(\mu \mathrm{g} / \mathrm{kg})\end{array}$ \\
\hline \multicolumn{3}{|c|}{ Anilide } \\
\hline Fenhexamid & 7.6 & 3.2 \\
\hline \multicolumn{3}{|c|}{ Aromatic } \\
\hline Chlorothalonil & 4.1 & 1.2 \\
\hline \multicolumn{3}{|c|}{ Azoles/Triazoles } \\
\hline Cyproconazole & 4.7 & 1.5 \\
\hline Difenoconazole & 10.5 & 0.6 \\
\hline Fenbuconazole & 5.2 & 2.2 \\
\hline Flusilazole & 4.5 & 3.0 \\
\hline Flutriafol & 4.2 & 1.3 \\
\hline Imazalil & 10.5 & 2.5 \\
\hline Metconazole & 5.2 & 0.7 \\
\hline Myclobutanil & 6.0 & 2.9 \\
\hline Propiconazole & 5.0 & 1.6 \\
\hline Tebuconazole & 3.7 & 1.6 \\
\hline Tetraconazole & 5.6 & 1.3 \\
\hline Triadimefon & 8.9 & 3.8 \\
\hline Triadimenol & 8.0 & 1.6 \\
\hline Triflumizole & 6.1 & 0.6 \\
\hline Triticonazole & 6.9 & 2.4 \\
\hline \multicolumn{3}{|c|}{ Benzamide } \\
\hline Zoxamide & 3.5 & 1.1 \\
\hline \multicolumn{3}{|c|}{ Carboxamide } \\
\hline Boscalid & 2.8 & 1.7 \\
\hline \multicolumn{3}{|c|}{ Imidazole/0xazole } \\
\hline Famoxadone & 2.5 & 2.4 \\
\hline Iprodione & 4.4 & 0.9 \\
\hline Vinclozolin & NA & 1.8 \\
\hline \multicolumn{3}{|c|}{ Morpholine } \\
\hline Dimethomorph & 6.0 & 2.0 \\
\hline \multicolumn{3}{|c|}{ Pyrimidine/Anilinopyrimidine } \\
\hline Cyprodinil & 7.4 & 2.4 \\
\hline Fenarimol & 6.5 & 1.5 \\
\hline Pyrimethanil & 4.1 & 1.2 \\
\hline \multicolumn{3}{|c|}{ Pyridine } \\
\hline Fluazinam & 4.4 & NA \\
\hline \multicolumn{3}{|c|}{ Pyrrole } \\
\hline Fludioxinil & 7.3 & 3.7 \\
\hline \multicolumn{3}{|c|}{ Strobilurins } \\
\hline Azoxystrobin & 3.1 & 1.1 \\
\hline Fluoxastrobin & 4.2 & 1.8 \\
\hline Kresoxim-methyl & 4.0 & 0.6 \\
\hline Pyraclostrobin & 2.9 & 1.6 \\
\hline Trifloxystrobin & 4.7 & 1.4 \\
\hline
\end{tabular}

\section{Sediment Organic Carbon and Nitrogen}

Bed-sediment samples were analyzed for organic carbon and nitrogen content by combustion and thermal conductivity by using a Perkin Elmer CHNS/O elemental analyzer (Perkin Elmer Corporation, Waltham, Mass.) according to a modified version of USEPA 440.0 (Zimmerman and others, 2007). Dry, homogenized sediments were combusted at $925^{\circ} \mathrm{C}$ in silver boats after being exposed to concentrated hydrochloric acid $(\mathrm{HCl})$ fumes in a desiccator for 24 hours to remove inorganic carbon. Before analysis, sediments were dried at $100^{\circ} \mathrm{C}$ for 3 hours. Acetanilide was used for instrument calibration. The instrument was calibrated with blanks and standards prior to sample analysis. Standards were required to be within 98 percent of the nominal value. Blanks, replicates, and standards were analyzed every 10 samples to assess instrument stability. Replicate samples were reanalyzed if the relative percentage difference between the two replicates was greater than 20 percent. Method detection limits for carbon and nitrogen were 0.01 percent.

\section{Quality Assurance/Quality Control Methods}

All data collected were evaluated by using a comprehensive set of performance-based quality assurance/ quality control (QA/QC) protocols, including laboratory blanks, replicate sample, matrix spikes, certified reference material, and surrogate recovery. All environmental and QC data were reviewed by project staff and by the USGS California Water Science Center Water-Quality Specialist.

\section{Dissolved Pesticides}

Prior to extraction, all samples were spiked with ring- ${ }^{13} \mathrm{C}_{3}$-atrazine and diethyl- $\mathrm{d}_{10}$ diazinon, which were used as recovery surrogates to assess the efficiency of sample extraction. Sample data were excluded if percentage recovery was less than 70 percent. Laboratory blanks (six) were processed to test the cleanliness of laboratory procedures. The criterion for laboratory blanks was that all compounds be absent (no discernable response in the chromatogram) or, if detected, had concentrations below their respective instrumental limits of detection. Three sequential replicates were collected to test the lab's ability to reproduce results. The criterion for replicate samples was that the relative percent difference for all compounds detected be less that 25 percent. If the criterion was not met, sample data were excluded. Laboratory matrix spikes (three) were analyzed for a suite of over 90 compounds. The criterion for matrix spiked samples was that the percentage recovery for all compounds ranged from 70 to 125 percent. 


\section{Glyphosate, AMPA, and Glufosinate}

Lab blanks and field replicates were analyzed to assess sample collection and processing, and instrument performance. The criterion for laboratory blanks was that all compounds be absent (no discernable response in the chromatogram) or, if detected, had concentrations below their respective instrumental limits of detection. Three sequential replicates were collected to test the lab's ability to reproduce results. The criterion for replicate samples was that the relative percent difference for all compounds detected would be less than 25 percent. If the criterion was not met, sample data were excluded.

\section{Dissolved Organic Carbon}

Laboratory blanks were analyzed with every batch of samples. The criterion for laboratory blanks was that all DOC be absent or, if detected, had concentrations below the MDL. Replicate samples (10) were collected for DOC quality-assurance purposes. The criterion for replicate samples was that all DOC measurements be within 10 percent of each other.

\section{Nutrients}

Field blanks and replicate samples were analyzed to assess sample collection and processing, and laboratory instrument QC performance. The criterion for laboratory blanks was that all inorganic constituents be absent or, if detected, had concentrations below the MDL. Five replicate sample pairs were analyzed, and the criterion for replicate samples was a relative percent difference between the environmental and replicate sample of less than 25 percent.

\section{Batrachochytrium dendroibatidis (Bd)}

During each analysis run, laboratory blanks were analyzed with the samples, and the criterion was a negative $B d$ value in all blanks. Replicates were analyzed with every sample collected from each site. The criteria for replicate samples were that any replicate samples that deviated were rerun, and, if the samples differed a second time, then the sample was considered negative for Bd. Therefore, a positive Bd result signifies that both replicates must yield a positive result. After qPCR results were finalized, data were validated, and results were reported as the average of two replicates per filter per sample. A zero value indicates that Bd was not detected in the sample. Results marked with the "c" code were identified by the laboratory as potentially affected by PCR inhibition, leading to a higher degree of uncertainty.

\section{Sediment-Associated Pesticides}

Prior to extraction, all samples were spiked with trifluralin- $\mathrm{d}^{10}$, ring- ${ }^{13} \mathrm{C}_{12}-p, p^{\prime}$ DDE and phenoxy- ${ }^{13} \mathrm{C}_{6}$-cispermethrin as recovery surrogates. If surrogate percentage recovery was less than 70 percent, samples were re-extracted. Laboratory blanks (three) consisting of approximately $5 \mathrm{~g}$ of baked sodium sulfate $\left(\mathrm{Na}_{2} \mathrm{SO}_{4}\right)$ as a sediment substitute were analyzed with every batch of 18 samples. The criterion for laboratory blanks was that all compounds would be absent (no discernable response in the chromatogram) or, if detected, would have concentrations below their respective instrumental limits of detection. Replicate samples (three) were analyzed with every batch of 18 samples. The criterion for replicate samples was that the relative percent difference for all compounds detected would be less than 25 percent. If the criterion was not met, samples were reextracted and analyzed. Laboratory matrix spikes (three) were analyzed with every batch of 18 samples. The criterion for matrix-spike samples was the percentage recovery for all compounds range from 70 to 125 percent. Standard reference material 1941b (SRM 1941b), Organics in Marine Sediment (National Institute of Standard, Gaithersburg, Md.) was chosen as an appropriate reference material for this study because no standard reference material is available for the current-use pesticides. The two compounds included in SRMI1941b used as standard reference compounds were $p, p$ '- DDD and $p, p^{\prime}$ - DDE. For results to be considered acceptable, calculated concentrations for all compounds had to fall within the 95 percent confidence intervals of the certified values.

\section{Sediment Organic Carbon and Nitrogen}

Instrument blanks were analyzed every 10 samples during batch processing. The criterion for laboratory blanks was that organic carbon and nitrogen values be less than the instrument calibrated blank value. Five replicate samples were analyzed to assess instrument performance, and results were considered acceptable if relative percent difference between the environmental and replicate samples for organic carbon was less than 30 percent. 


\section{Results}

\section{Dissolved Pesticides}

\section{National Network}

A total of 24 pesticides were detected in one or more of the 54 water samples, including 7 fungicides, 10 herbicides, 4 insecticides, 1 synergist, and 2 pesticide degradates (tables 5 and 6 ). AMPA, the primary degradate of the herbicide glyphosate, which is the active ingredient in Roundup ${ }^{\circledR}$, was the most frequently detected pesticide in water ( 30 percent) followed by glyphosate (15 percent). The maximum number of pesticides observed at a single site was 9 compounds in a water sample from at a site in Louisiana (Bayou Amy near Henderson, La.; fig. 3). Pesticide concentration in water collected from sites in the seven states ranged from less than the method detection limits to $2,880 \mathrm{ng} / \mathrm{L}$. The compounds with the highest concentrations were the herbicide, clomazone at 2,880 $\mathrm{ng} / \mathrm{L}$; the insecticide, malathion at 2,840 $\mathrm{ng} / \mathrm{L}$; and the herbicide, glyphosate at $1.63 \mu \mathrm{g} / \mathrm{L}$, which were observed in water collected from Louisiana, Oregon, and Idaho, respectively (tables 5 and $\underline{6}$ ).

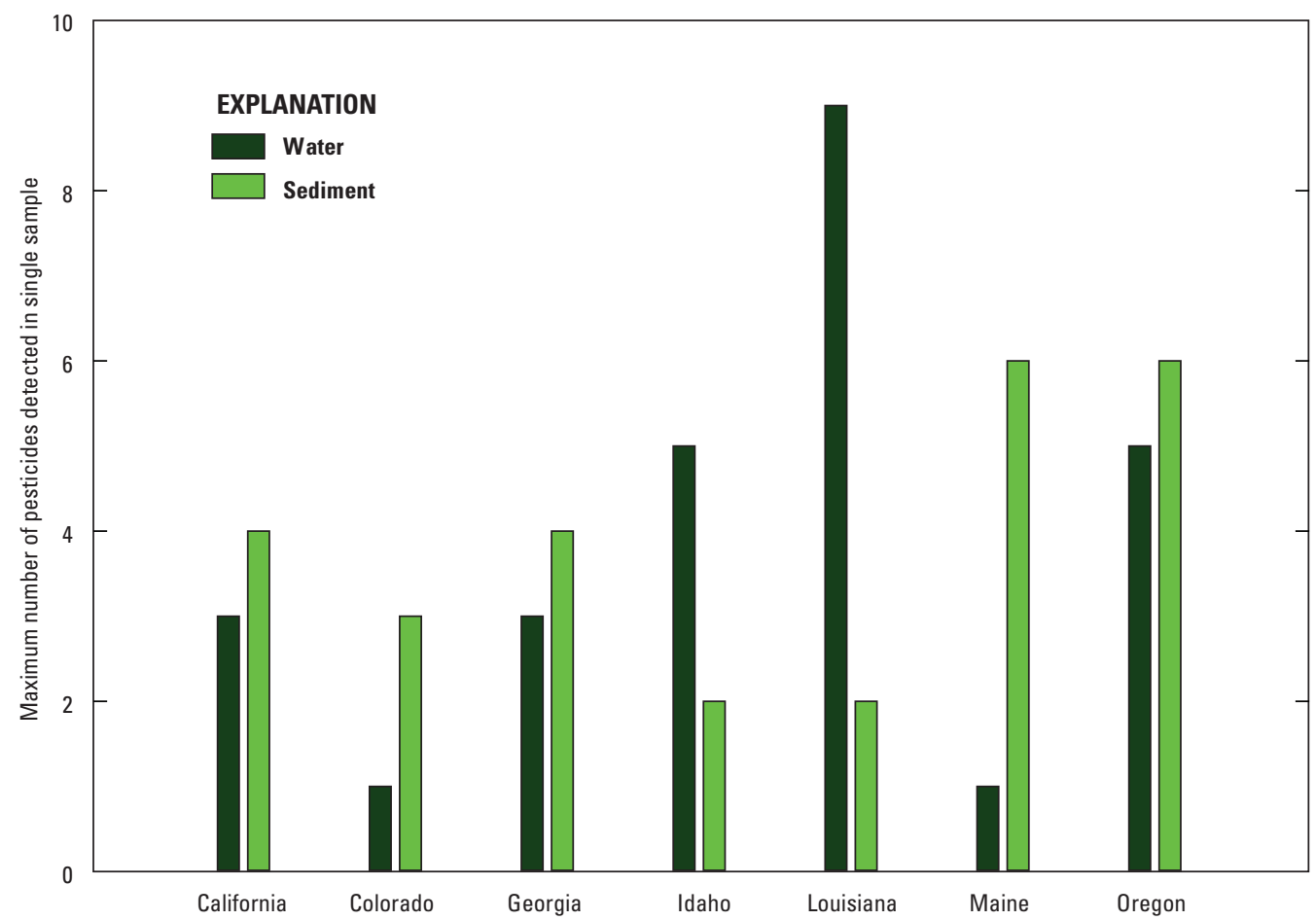

Figure 3. Maximum numbers of pesticides detected in water and sediment samples collected from sites in seven states during 2009 and 2010. 


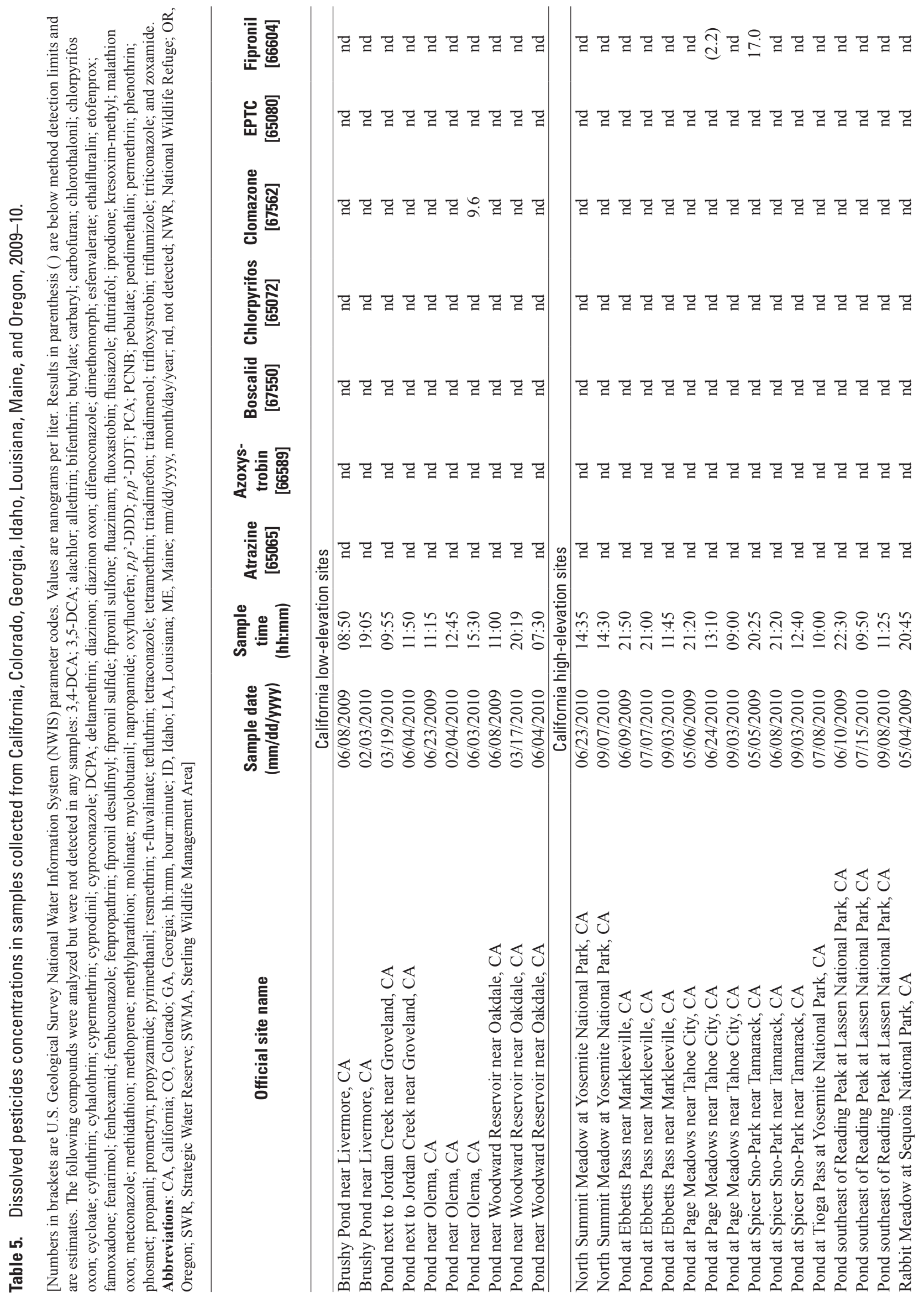




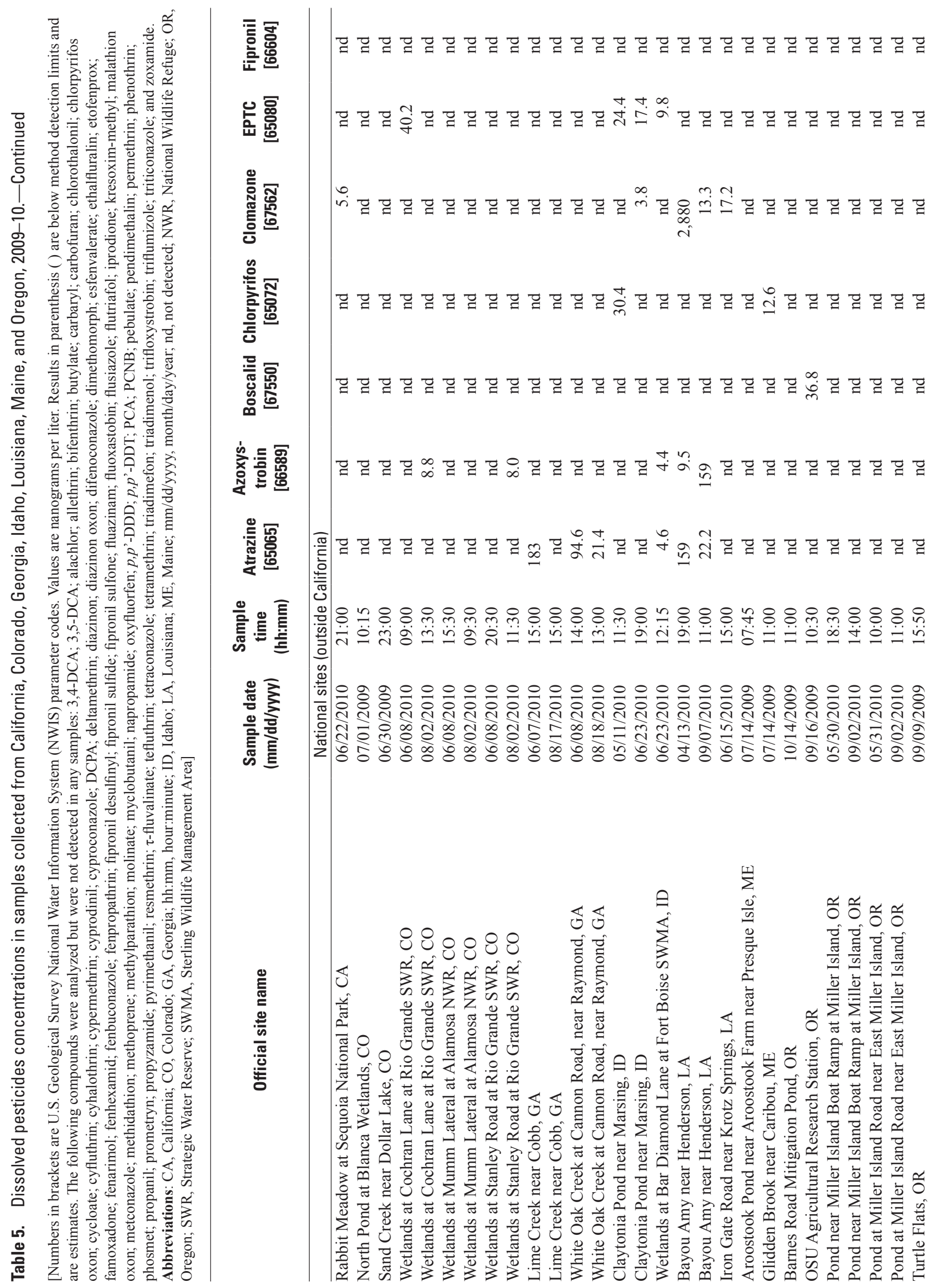




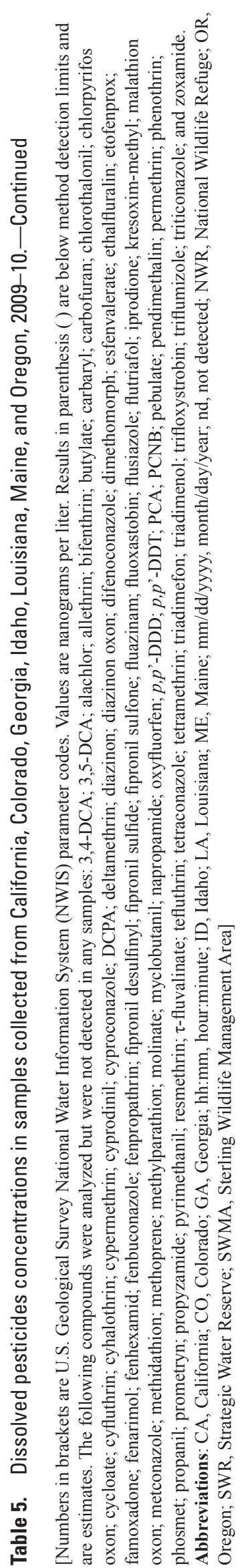

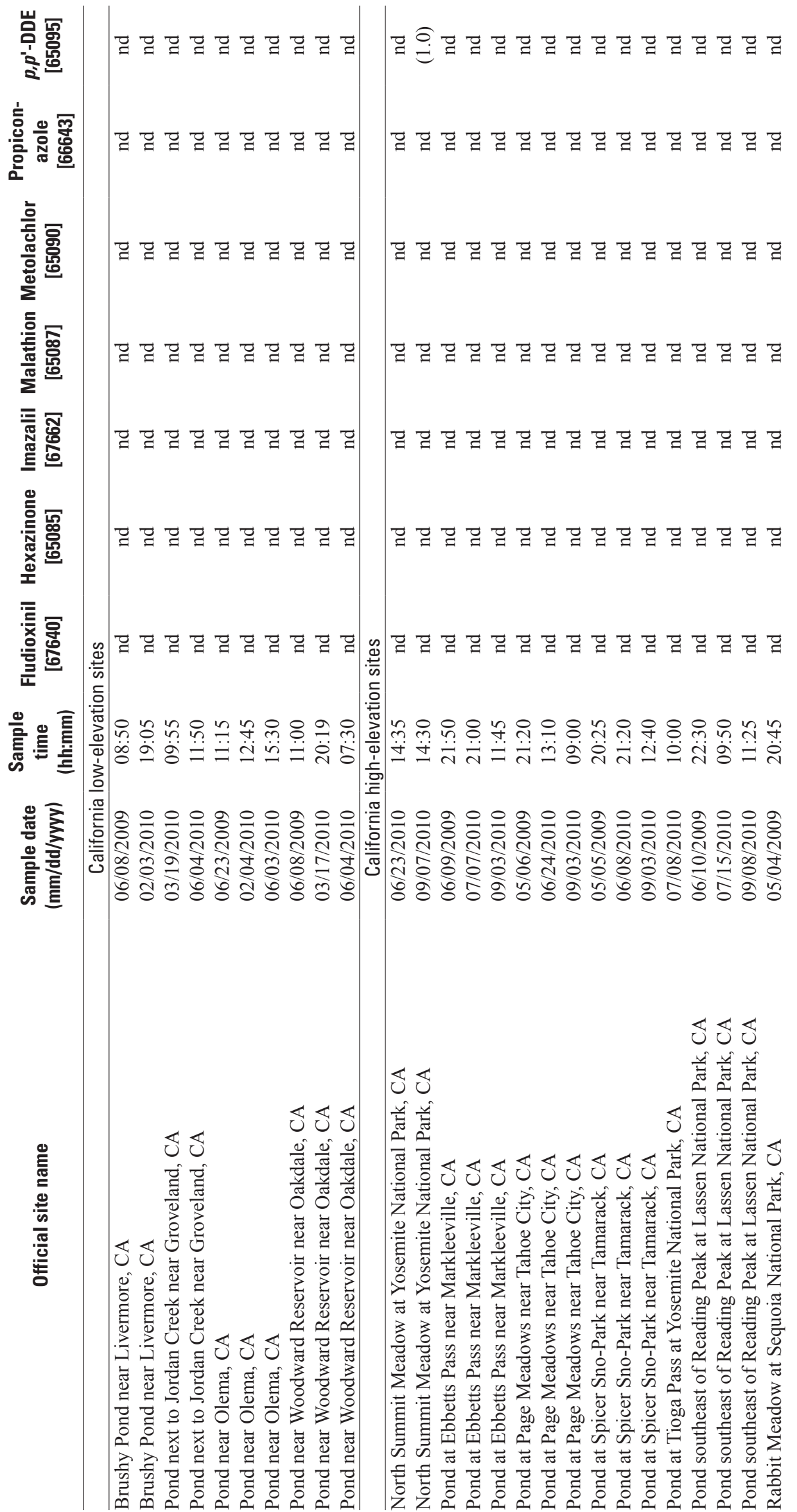




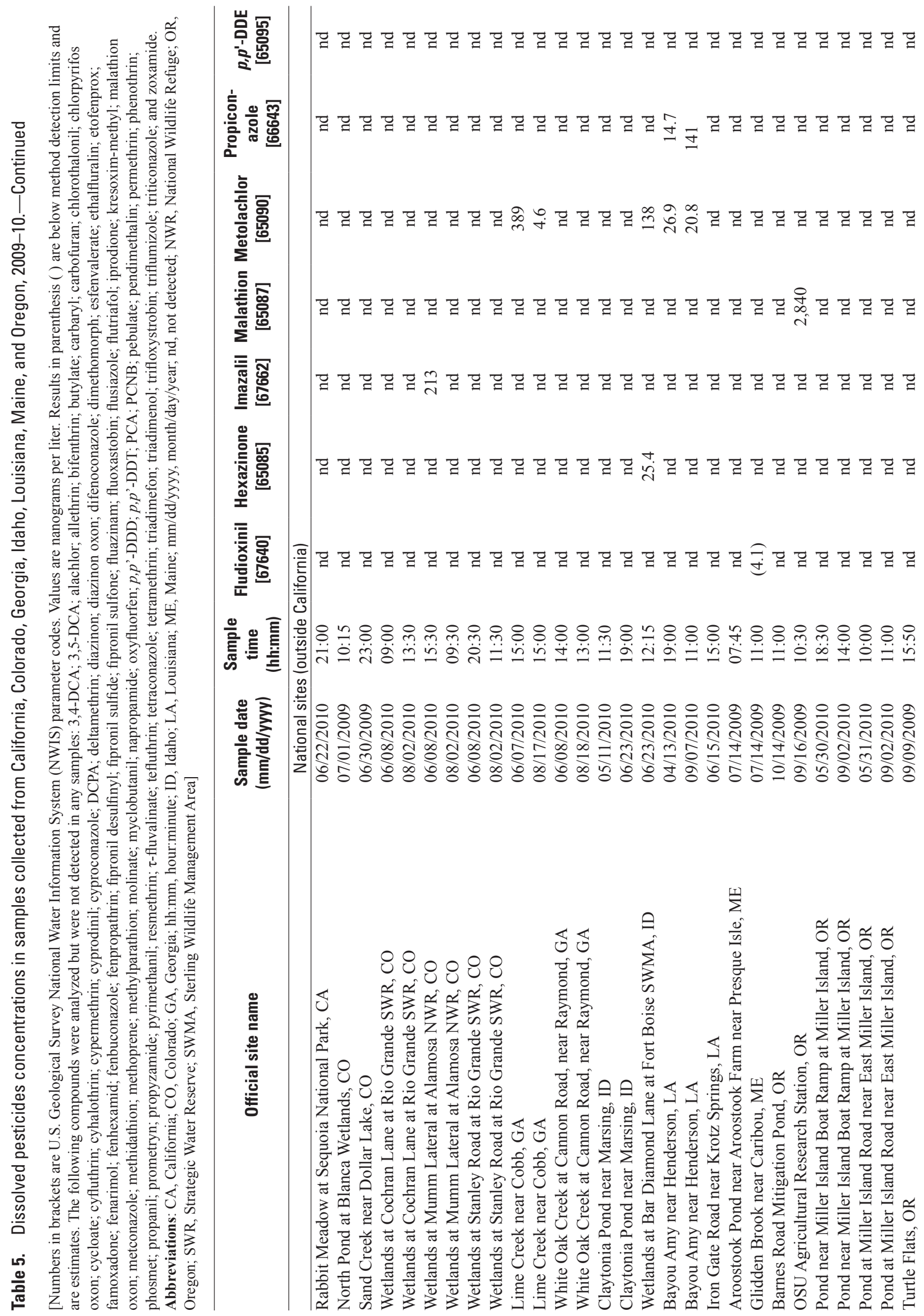




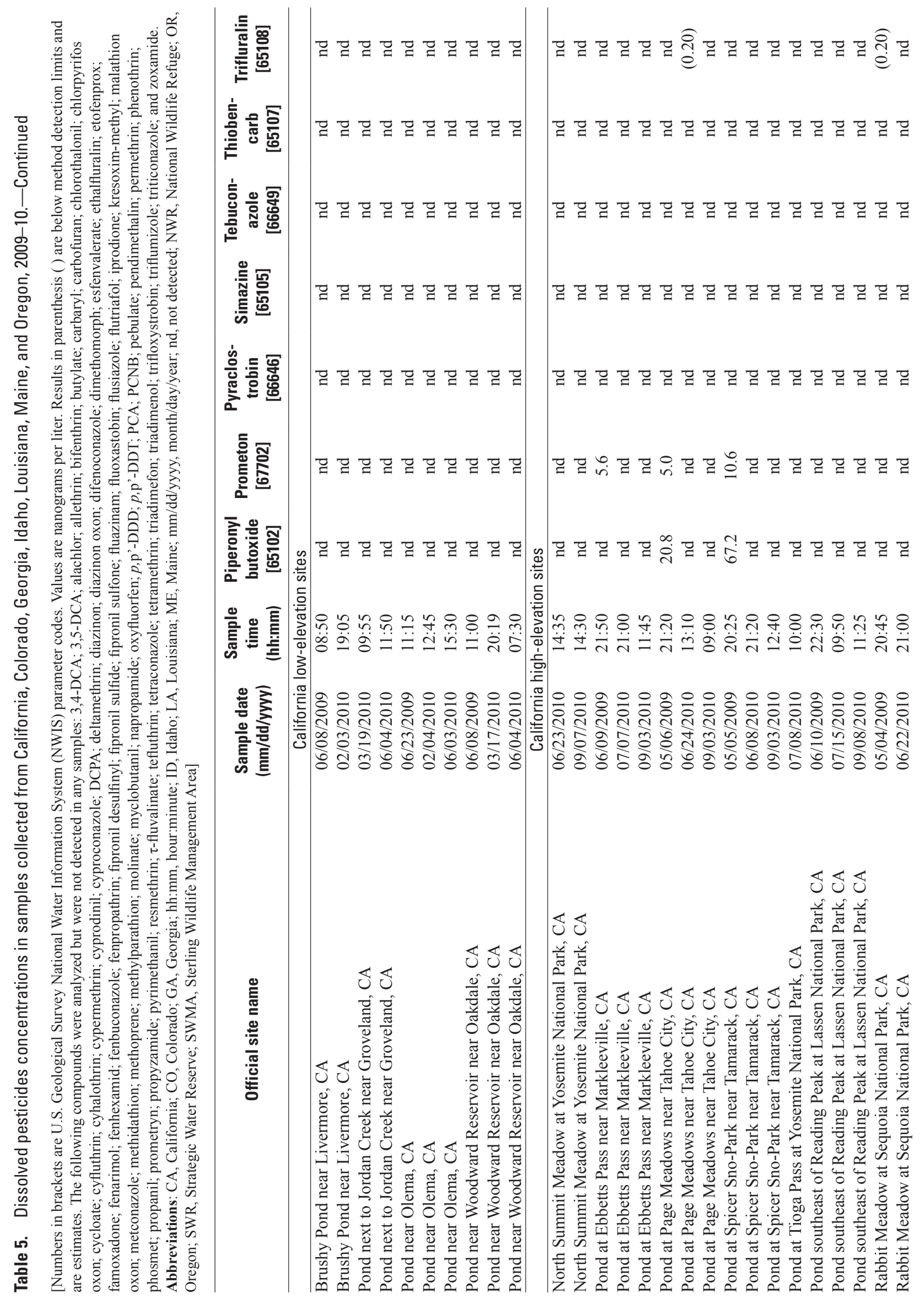




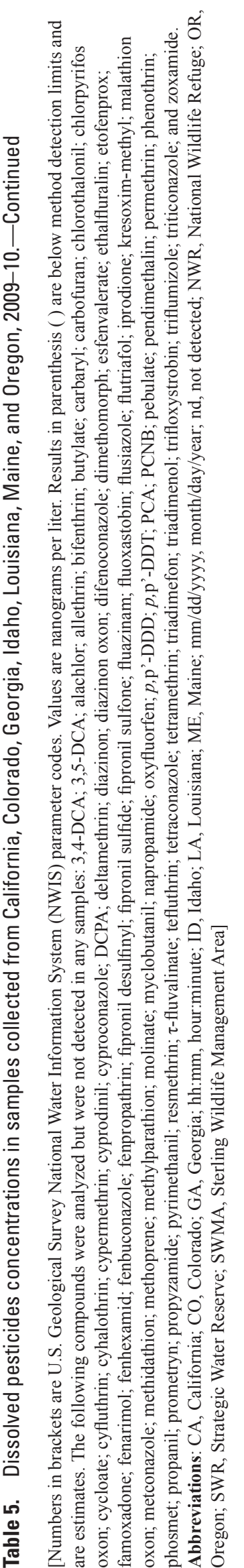

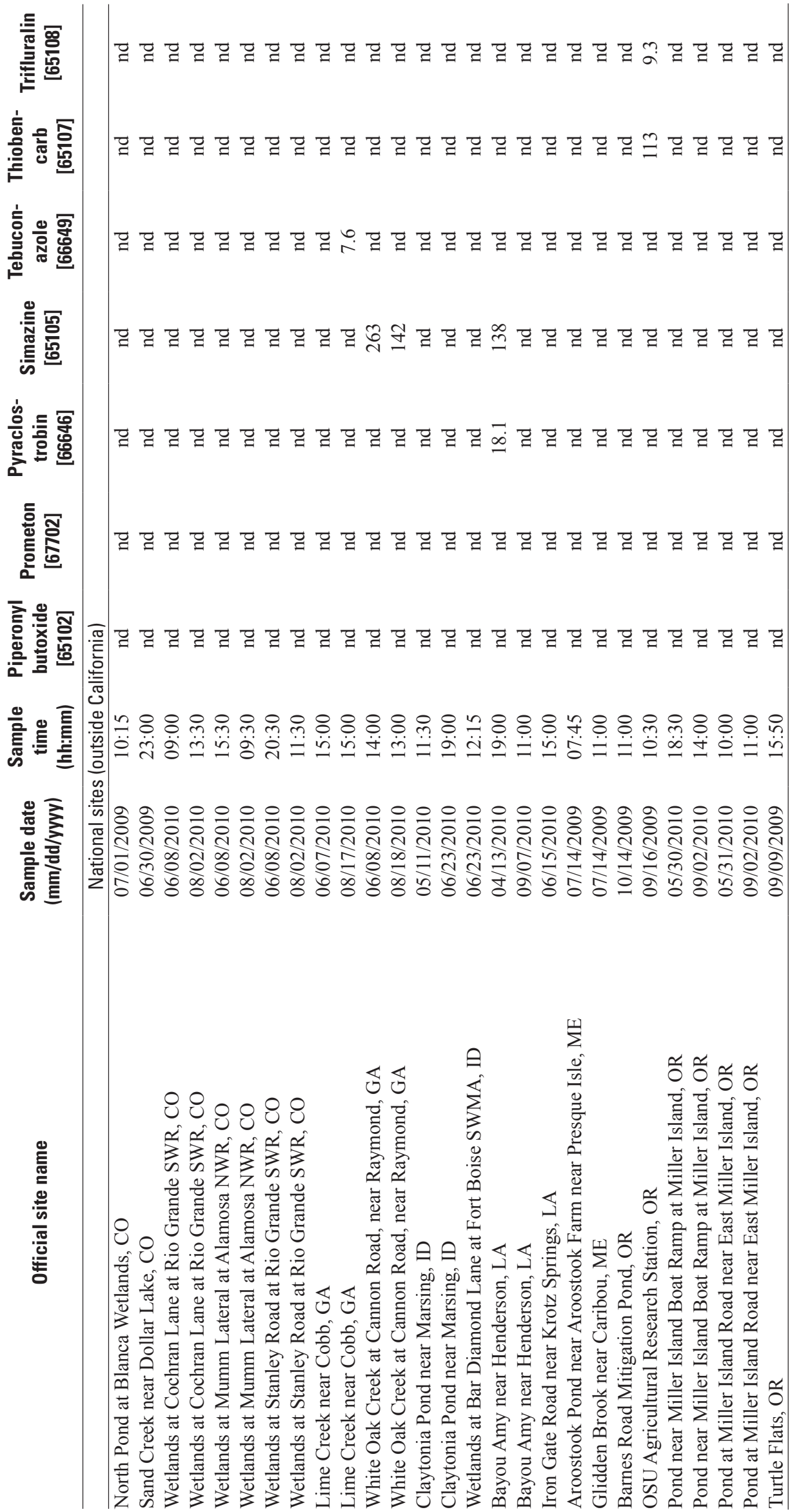


Table 6. Dissolved concentrations of aminomethylphosphonic acid (AMPA) and glyphosate in samples collected from California, Colorado, Georgia, Idaho, Louisiana, Maine, and Oregon, 2009-10.

[Numbers in brackets are U.S. Geological Survey National Water Information System (NWIS) parameter codes. Values are in micrograms per liter. The following compound was analyzed but was not detected in any samples: glufonsinate. Abbreviations: CA, California; CO, Colorado; GA, Georgia; ID, Idaho; LA, Louisiana; ME, Maine; nd, not detected; NWR, National Wildlife Refuge; OR, Oregon; SWR, Strategic Water Reserve; SWMA, Sterling Wildlife Management Area]

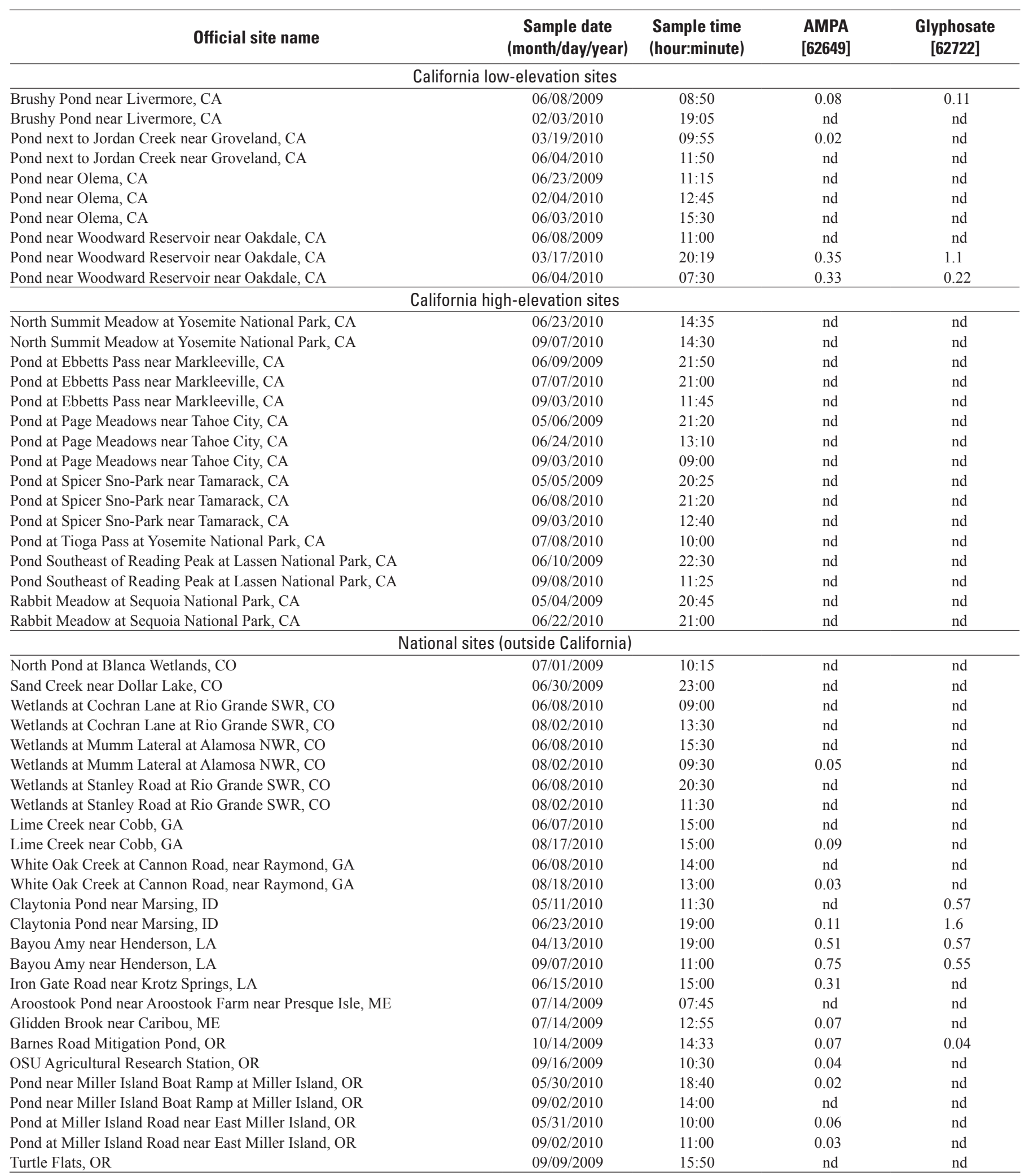




\section{California Sites}

In 27 water samples collected from 11 sites along north-south and east-west transects in California, 8 pesticides were detected (tables 5 and $\underline{6}$ ). Pesticide concentrations in water samples ranged from less than the method detection limit to $1.1 \mu \mathrm{g} / \mathrm{L}$ (glyphosate), and detection frequencies for individual pesticides ranged from 4 to 15 percent. AMPA, a degradate of glyphosate, was the most frequently detected pesticide in samples from California collected in 2009 and 2010 at 15 percent, followed by glyphosate at 11 percent, and prometon at 11 percent.

Only one pesticide, clomazone, was detected at both the high- and low-elevation sites in California, while five were detected only at the higher elevations (tables 5 and 6 ). Two of the most frequently detected compounds, AMPA and glyphosate, were observed only in samples collected from the low-elevation sites (table 6). Prometon, a triazine herbicide, was the most frequently detected pesticide at the high elevation sites, where it was found in 18 percent of the samples. Pesticide concentrations at the low-elevation sites ranged from less than the analytical detection limit to $1.1 \mu \mathrm{g} / \mathrm{L}$ (glyphosate), and concentrations at the high-elevation sites ranged from less than the method detection limit to $67.2 \mathrm{ng} / \mathrm{L}$ (piperonyl butoxide).

\section{Dissolved Organic Carbon}

DOC concentrations ranged from 1.1 to $135 \mathrm{mg} / \mathrm{L}$ in samples collected from California (table 7). Average DOC concentrations were higher at the low-elevation sites compared to the high-elevation sites in California (table 7). DOC concentrations ranged from 2.8 to $45.0 \mathrm{mg} / \mathrm{L}$ in samples from Colorado, from 2.1 to $3.3 \mathrm{mg} / \mathrm{L}$ in samples from Georgia, from 5.5 to $12.2 \mathrm{mg} / \mathrm{L}$ in samples from Idaho, from 6.0 to $13.1 \mathrm{mg} / \mathrm{L}$ in samples from Louisiana, from 7.1 to $22.6 \mathrm{mg} / \mathrm{L}$ in samples from Oregon, and were 2.3 and $6.4 \mathrm{mg} / \mathrm{L}$ in the two samples from Maine (table 8).

\section{Water-Quality Parameters and Nutrients}

Results from the analysis of water-quality parameters (temperature, specific conductance, $\mathrm{pH}$, dissolved oxygen, and turbidity) for each sampling event are shown in tables 7 and $\underline{8}$. Total nitrogen and phosphorus, as well as orthophosphorus and nitrate plus nitrite, were analyzed in most of the water samples. Results from these analyses are shown in tables 8 and $\underline{9}$.

\section{Batrachochytrium dendroibatidis Detections in Water}

Forty-five water samples from 29 sites in 7 states were analyzed for the fungus, Batrachochytrium dendrobatidis (Bd), measured in zoospore equivalents per liter of water. Three (Georgia, Louisiana, and Oregon) of the seven states had no detectable $\mathrm{Bd}$ in surface-water samples (table 10). $\mathrm{Bd}$ was detected in one or more samples from California at 6 of 11 sites, from Colorado at 2 of 3 sites, from Idaho at 2 of 2 sites, and from Maine at 1 of 2 sites. In some cases, Bd was not detected in any of three filters collected from a single site. When detected, the number of zoospore equivalents per liter of water ranged from 1.6 to 343 (table 10).

\section{Sediment-Bound Pesticides}

\section{National Sites}

A total of 22 pesticides were detected in 42 bed-sediment samples, including 9 fungicides, 5 herbicides, 5 insecticides, and 3 pesticide degradates (table 11). The most frequently detected compounds in sediment were the fungicides, pyraclostrobin at 40 percent and tebuconazole at 29 percent), and a pyrethroid insecticide, bifenthrin, at 36 percent. The sites with the highest numbers of pesticides were in Maine and Oregon with six pesticides detected in one sample in each of the states (fig. 3). Pesticide concentrations in bed sediment collected nationally ranged from less than their respective method detection limits to 1,380 micrograms per kilogram (tebuconazole in California).

\section{California Sites}

In California, 10 pesticides were detected in 22 bed-sediment samples collected from 11 sites along north-south and east-west transects in California (table 11). Pesticide concentrations in sediment ranged from less than the method detection limit to $1,380 \mu \mathrm{g} / \mathrm{kg}$ dry weight (tebuconazole), and detection frequencies ranged from 5 to 45 percent. Two fungicides, pyraclostrobin at 45 percent and tebuconazole at 41 percent, as well as the pyrethroid insecticide, bifenthrin at 32 percent, were the three most frequently detected pesticides in bed-sediment samples collected from sites within California. 


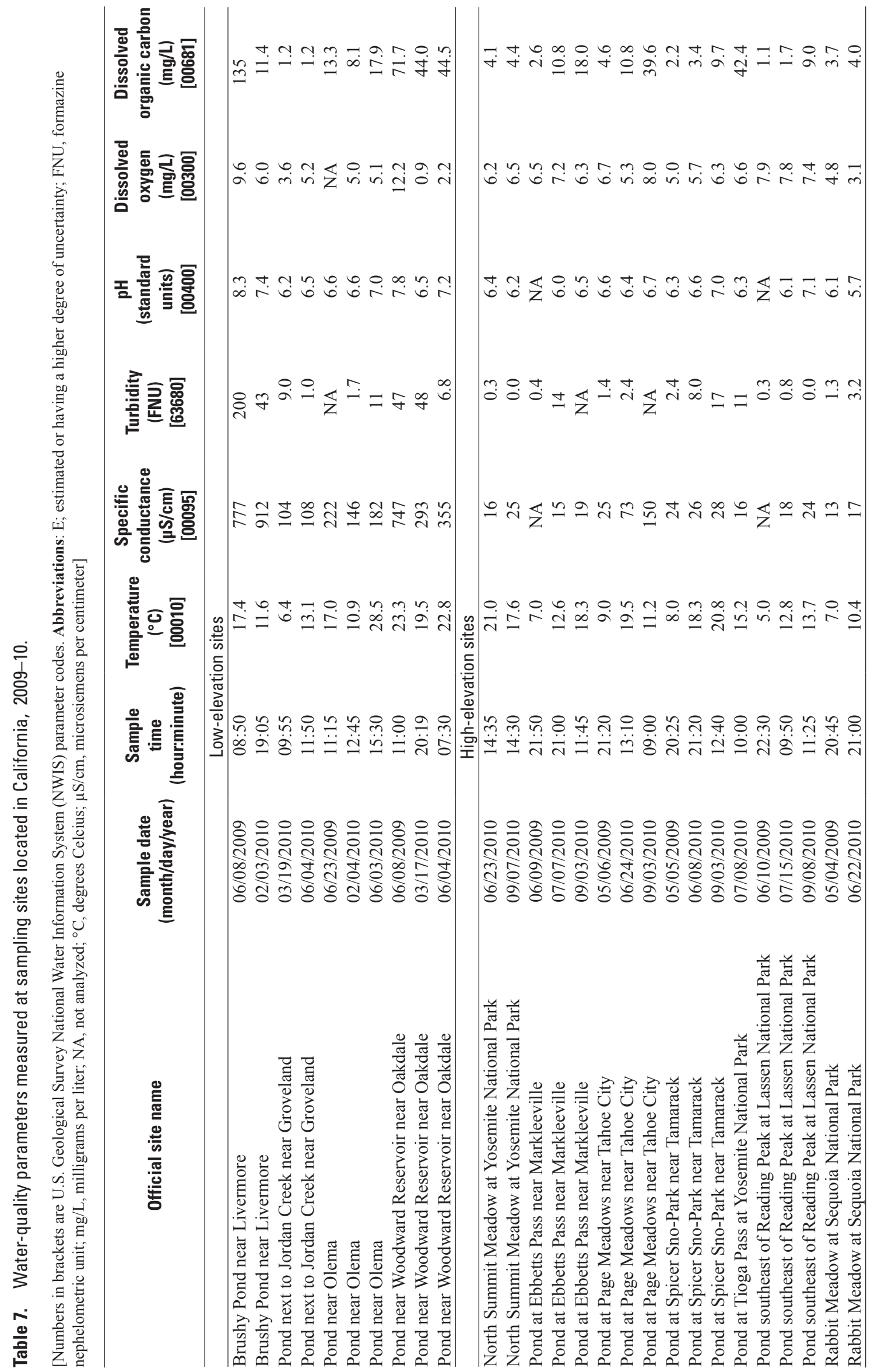




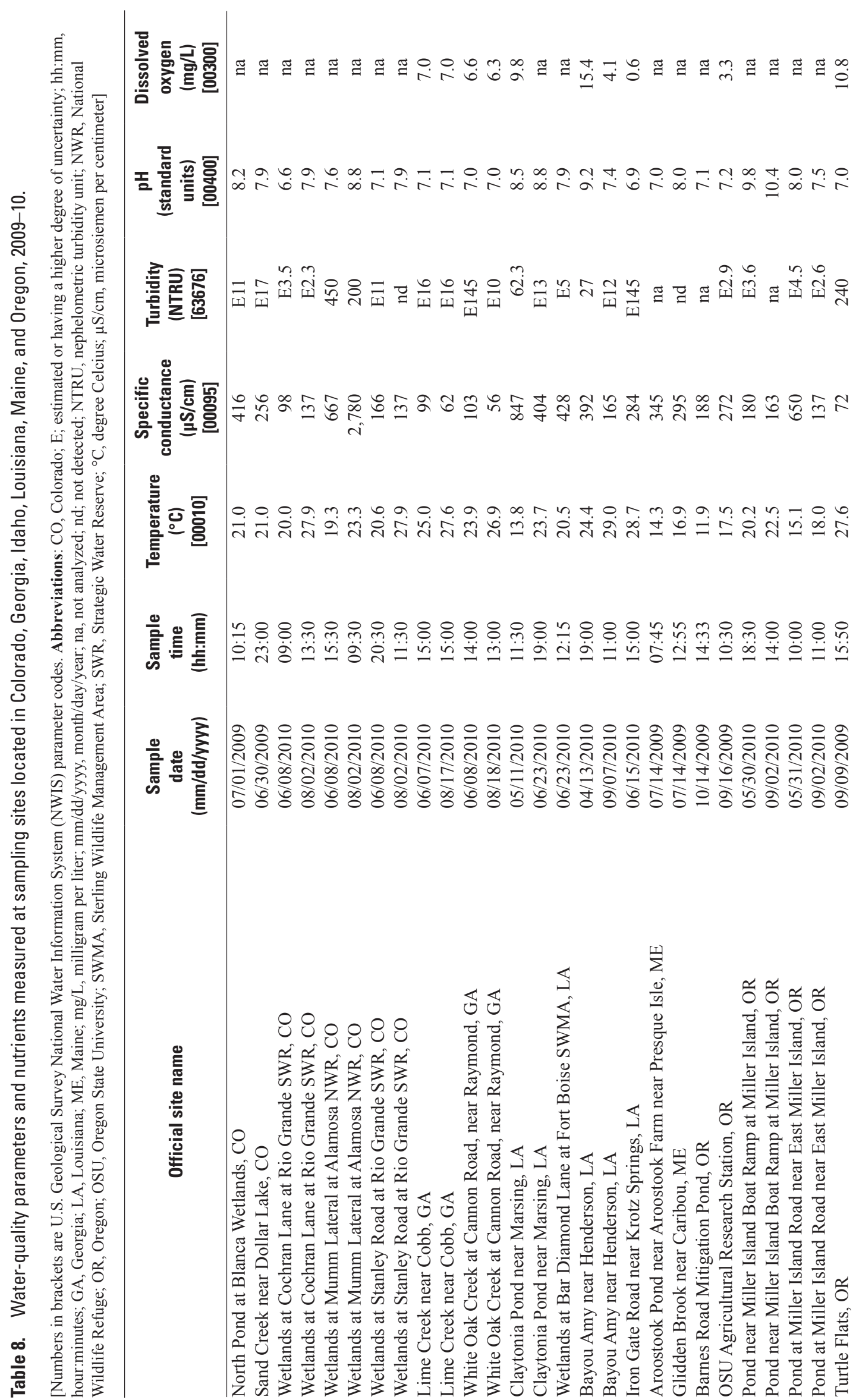




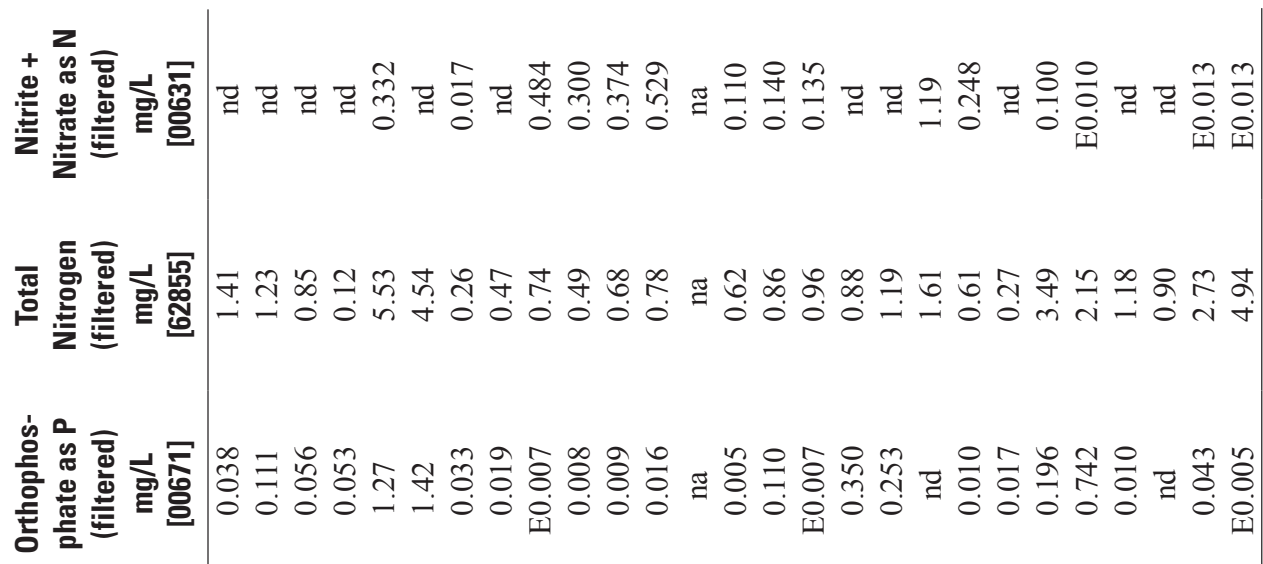

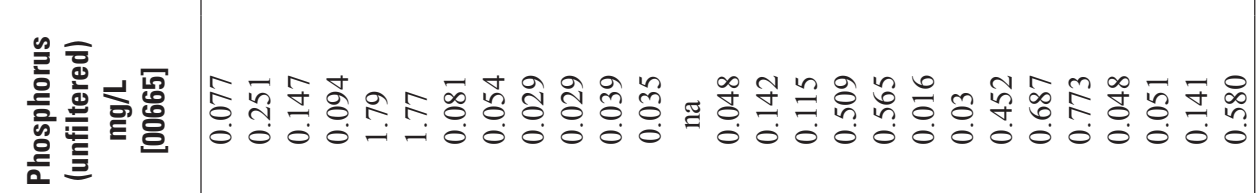

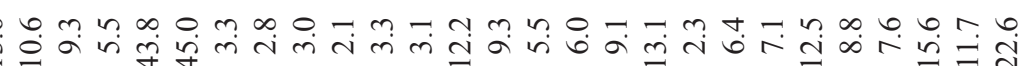
总

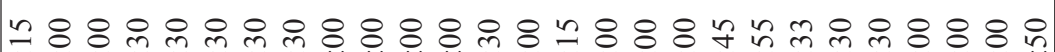

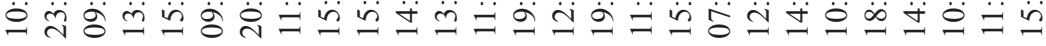

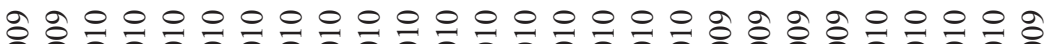

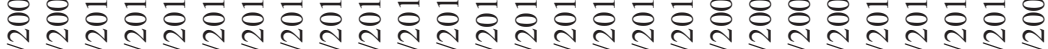
б o $\infty$ ती 형 


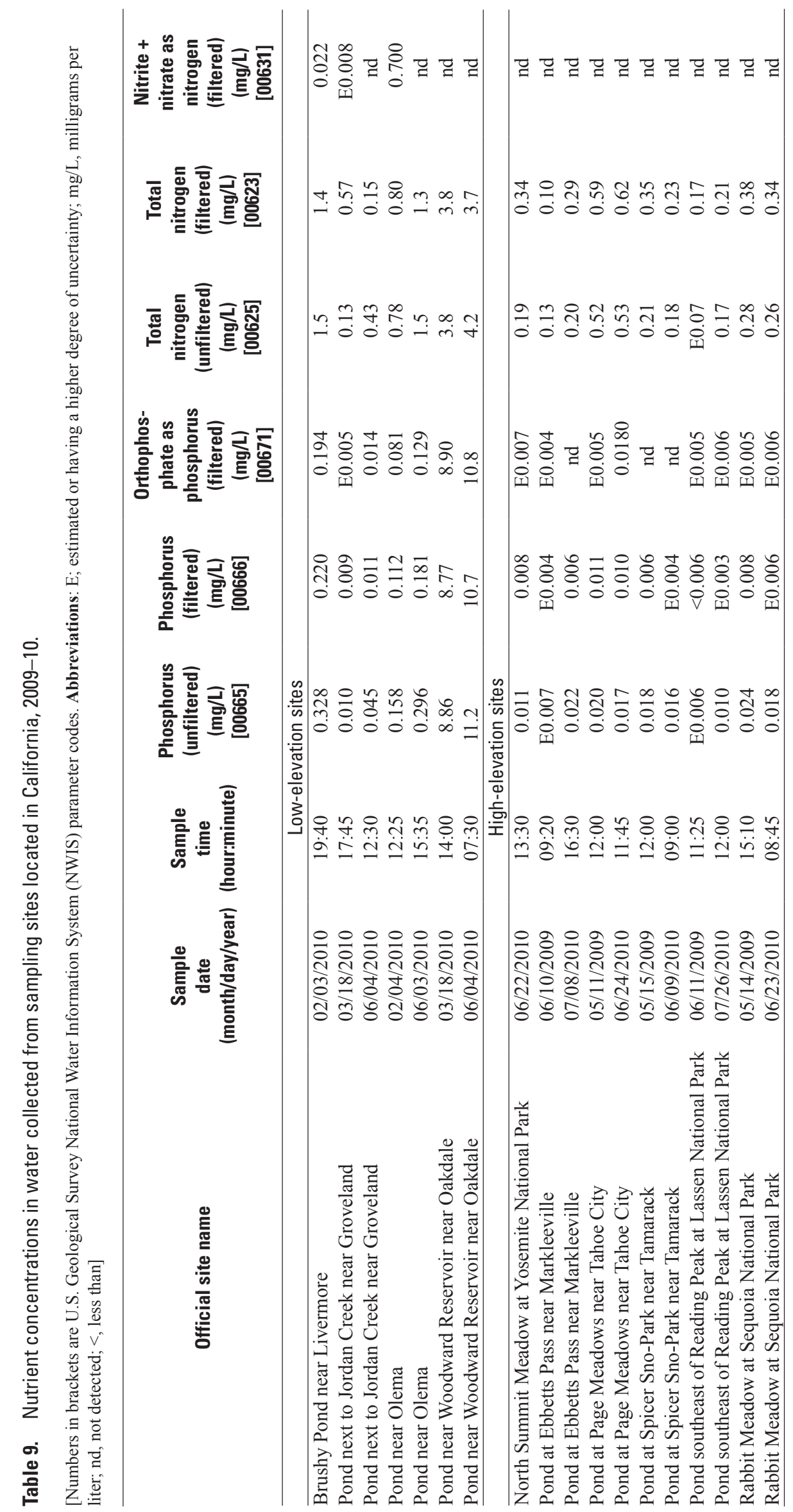


Table 10. Batrachochytrium dendrobatidis (Bd) in surface water collected from sites in California, Colorado, Georgia, Idaho, Louisiana, Maine, and Oregon, 2009-10.

[Abbreviations: c, results potentially affected by PCR inhibition, leading to a higher degree of uncertainty; CA, California; CO, Colorado; GA, Georgia; ID, Idaho; LA, Louisiana; ME, Maine; NA, not applicable; NWR, National Wildlife Refuge; OR, Oregon; OSU, Oregon State University; SWR, Strategic Water Reserve; SWMA, Sterling Wildlife Management Area; zoospore equiv/L, zoospore equivalent per liter]

\begin{tabular}{|c|c|c|c|c|}
\hline Official site name & $\begin{array}{c}\text { Date of Bd } \\
\text { sample collection } \\
\text { (month/day/year) }\end{array}$ & $\begin{array}{l}\text { Bd filters } \\
\text { (number) }\end{array}$ & $\begin{array}{l}\text { Bd detections } \\
\text { in filters } \\
\text { (number) }\end{array}$ & $\begin{array}{c}\text { Mean of } 2 \text { replicates } \\
\text { for each filter } \\
\text { (zoospore equiv/L) }\end{array}$ \\
\hline Brushy Pond near Livermore, CA & $06 / 08 / 2009$ & NA & NA & NA \\
\hline Brushy Pond near Livermore, CA & $02 / 03 / 2010$ & 3 & 2 & $0 / 133 / 63.0$ \\
\hline Pond next to Jordan Creek near Groveland, CA & $03 / 19 / 2010$ & 3 & 0 & $0 / 0 / 0$ \\
\hline Pond near Olema, CA & $02 / 04 / 2010$ & NA & NA & NA \\
\hline Pond near Olema, CA & $06 / 03 / 2010$ & 3 & 2 & $0 / 13.6 / 36.1$ \\
\hline Pond near Woodward Reservoir near Oakdale, CA & 06/08/2009 & NA & NA & NA \\
\hline Pond near Woodward Reservoir near Oakdale, CA & $03 / 18 / 2010$ & 3 & 0 & $0 / 0 / 0$ \\
\hline Pond near Woodward Reservoir near Oakdale, CA & $06 / 04 / 2010$ & 3 & 0 & $0 / 0 / 0$ \\
\hline Pond at Ebbetts Pass near Markleeville, CA & 07/07/2010 & 2 & 0 & $0 / 0$ \\
\hline Pond at Ebbetts Pass near Markleeville, CA & 09/01/2010 & 3 & 1 & $0 / 6.9 / 0$ \\
\hline Pond at Page Meadows near Tahoe City, CA & $05 / 11 / 2009$ & 3 & 0 & $0 / 0 / 0$ \\
\hline Pond at Page Meadows near Tahoe City, CA & $06 / 24 / 2010$ & 3 & 0 & $0 / 0 / 0$ \\
\hline Pond at Page Meadows near Tahoe City, CA & 09/01/2010 & 3 & 0 & $0 / 0 / 0$ \\
\hline Pond at Spicer Sno-Park near Tamarack, CA & $05 / 15 / 2009$ & 3 & 0 & $0 / 0 / 0$ \\
\hline Pond at Spicer Sno-Park near Tamarack, CA & $06 / 08 / 2010$ & 3 & 1 & $0 / 8.7 / 0$ \\
\hline Pond at Spicer Sno-Park near Tamarack, CA & $09 / 01 / 2010$ & 3 & 0 & $0 / 0 / 0$ \\
\hline Pond at Tioga Pass at Yosemite National Park, CA & $07 / 08 / 2010$ & 3 & 0 & $0 / 0 / 0$ \\
\hline Pond southeast of Reading Peak at Lassen National Park, CA & $06 / 11 / 2009$ & 3 & 0 & $0 / 0 / 0$ \\
\hline Pond southeast of Reading Peak at Lassen National Park, CA & $07 / 15 / 2010$ & 3 & 0 & $0 / 0 / 0$ \\
\hline
\end{tabular}


Table 10. Batrachochytrium dendrobatidis $(\mathrm{Bd})$ in surface water collected from sites in California, Colorado, Georgia, Idaho, Louisiana, Maine, and Oregon, 2009-10.-Continued

[Abbreviations: c, results potentially affected by PCR inhibition, leading to a higher degree of uncertainty; CA, California; CO, Colorado; GA, Georgia; ID, Idaho; LA, Louisiana; ME, Maine; NA, not applicable; NWR, National Wildlife Refuge; OR, Oregon; OSU, Oregon State University; SWR, Strategic Water Reserve; SWMA, Sterling Wildlife Management Area; zoospore equiv/L, zoospore equivalent per liter]

\begin{tabular}{|c|c|c|c|c|}
\hline Official site name & $\begin{array}{c}\text { Date of } \mathrm{Bd} \\
\text { sample collection } \\
\text { (month/day/year) }\end{array}$ & $\begin{array}{l}\text { Bd filters } \\
\text { (number) }\end{array}$ & $\begin{array}{l}\text { Bd detections } \\
\text { in filters } \\
\text { (number) }\end{array}$ & $\begin{array}{l}\text { Mean of } 2 \text { replicates } \\
\text { for each filter } \\
\text { (zoospore equiv/L) }\end{array}$ \\
\hline North Pond at Blanca Wetlands, CO & $07 / 01 / 2009$ & 3 & 0 & $0 / 0 / 0$ \\
\hline Sand Creek near Dollar Lake, CO & 06/30/2009 & 3 & 0 & $0 / 0 / 0$ \\
\hline Wetlands at Cochran Lane at Rio Grande SWR, CO & 06/08/2010 & 3 & 1 & $39.0 / 0 / 0$ \\
\hline Wetlands at Mumm Lateral at Alamosa NWR, CO & $08 / 02 / 2010$ & 3 & 0 & $0 / 0 / 0$ \\
\hline Wetlands at Stanley Road at Rio Grande SWR, CO & $06 / 08 / 2010$ & 3 & 1 & $\mathrm{c} 21.0 / 0 / 0$ \\
\hline Wetlands at Stanley Road at Rio Grande SWR, CO & $08 / 02 / 2010$ & 3 & 1 & $0 / 0 / 7.9$ \\
\hline Lime creek near Cobb, GA & $06 / 07 / 2010$ & 3 & 0 & $0 / 0 / 0$ \\
\hline Lime creek near Cobb, GA & $08 / 17 / 2010$ & NA & NA & NA \\
\hline Wetlands at Bar Diamond Lane at Fort Boise SWMA, ID & $06 / 23 / 2010$ & 3 & 1 & $\mathrm{c} 5.6 / 0 / 0$ \\
\hline Bayou Amy near Henderson, LA & $04 / 13 / 2010$ & 3 & 0 & $0 / 0 / 0$ \\
\hline Bayou Amy near Henderson, LA & 09/07/2010 & 2 & 0 & $0 / 0$ \\
\hline Iron Gate Road near Krotz Springs, LA & $06 / 15 / 2010$ & 3 & 0 & $0 / 0 / 0$ \\
\hline Aroostook Pond near Aroostook Farm near Presque Isle, ME & $07 / 14 / 2009$ & 3 & 3 & $343 / 33.0 / 9.0$ \\
\hline Glidden Brook near Caribou, ME & $07 / 14 / 2009$ & 3 & 0 & $0 / 0 / 0$ \\
\hline Barnes Mitigation Pond, Beaverton, OR & $10 / 14 / 2009$ & NA & NA & NA \\
\hline OSU Agricultural Station near Klamath Falls & 09/16/2009 & NA & NA & NA \\
\hline Pond near Miller Island Boat Ramp at Miller Island, OR & $05 / 30 / 2010$ & 3 & 0 & $0 / 0 / 0$ \\
\hline Pond near Miller Island Boat Ramp at Miller Island, OR & 09/01/2010 & 3 & 0 & $0 / 0 / 0$ \\
\hline Pond at Miller Island Road near East Miller Island, OR & $05 / 31 / 2010$ & 3 & 0 & $0 / 0 / 0$ \\
\hline
\end{tabular}




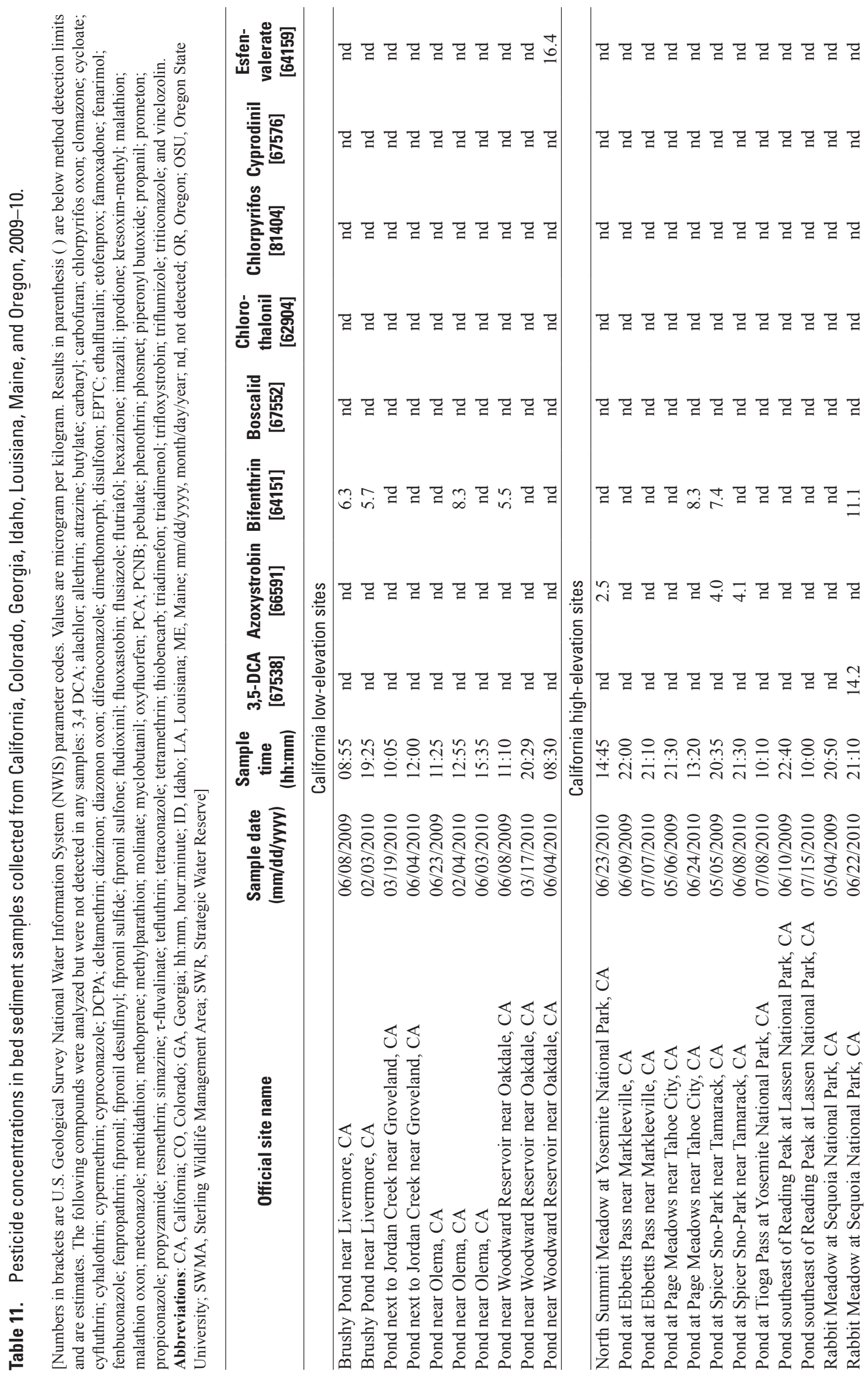




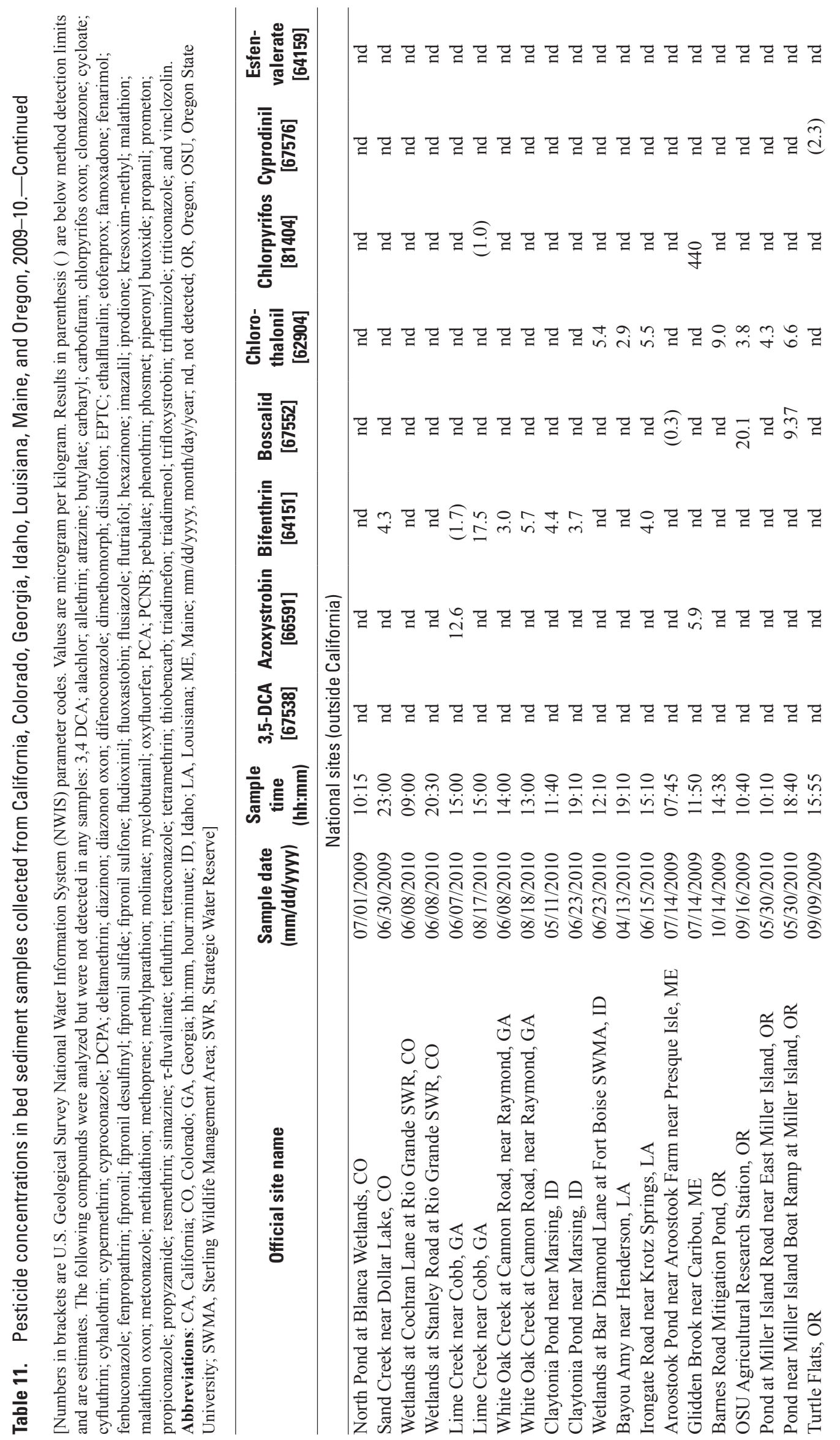


Occurrence of Pesticides in Water and Sediment Collected from Amphibian Habitats Located Throughout the United States, 2009-10

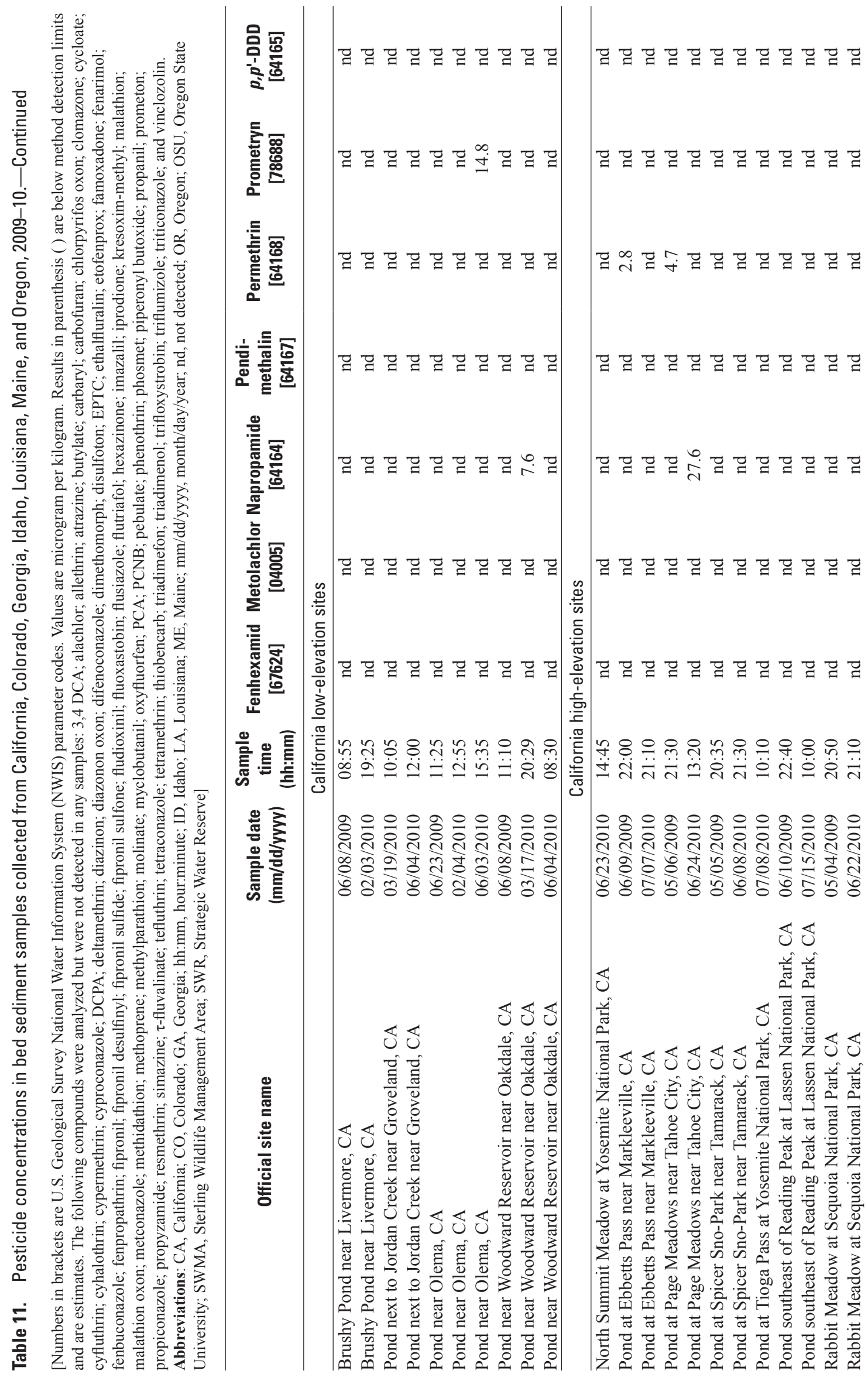




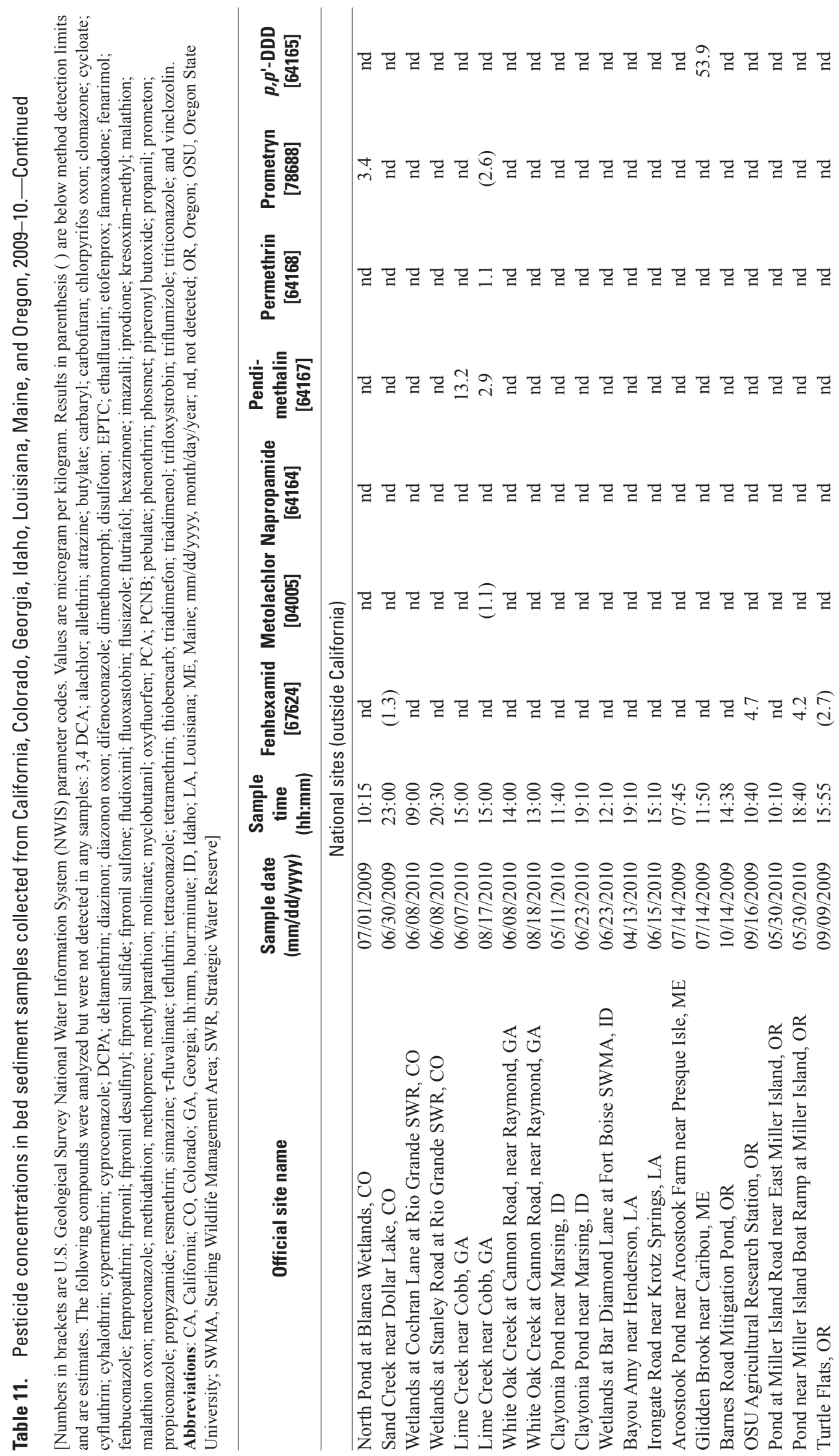


Occurrence of Pesticides in Water and Sediment Collected from Amphibian Habitats Located Throughout the United States, 2009-10

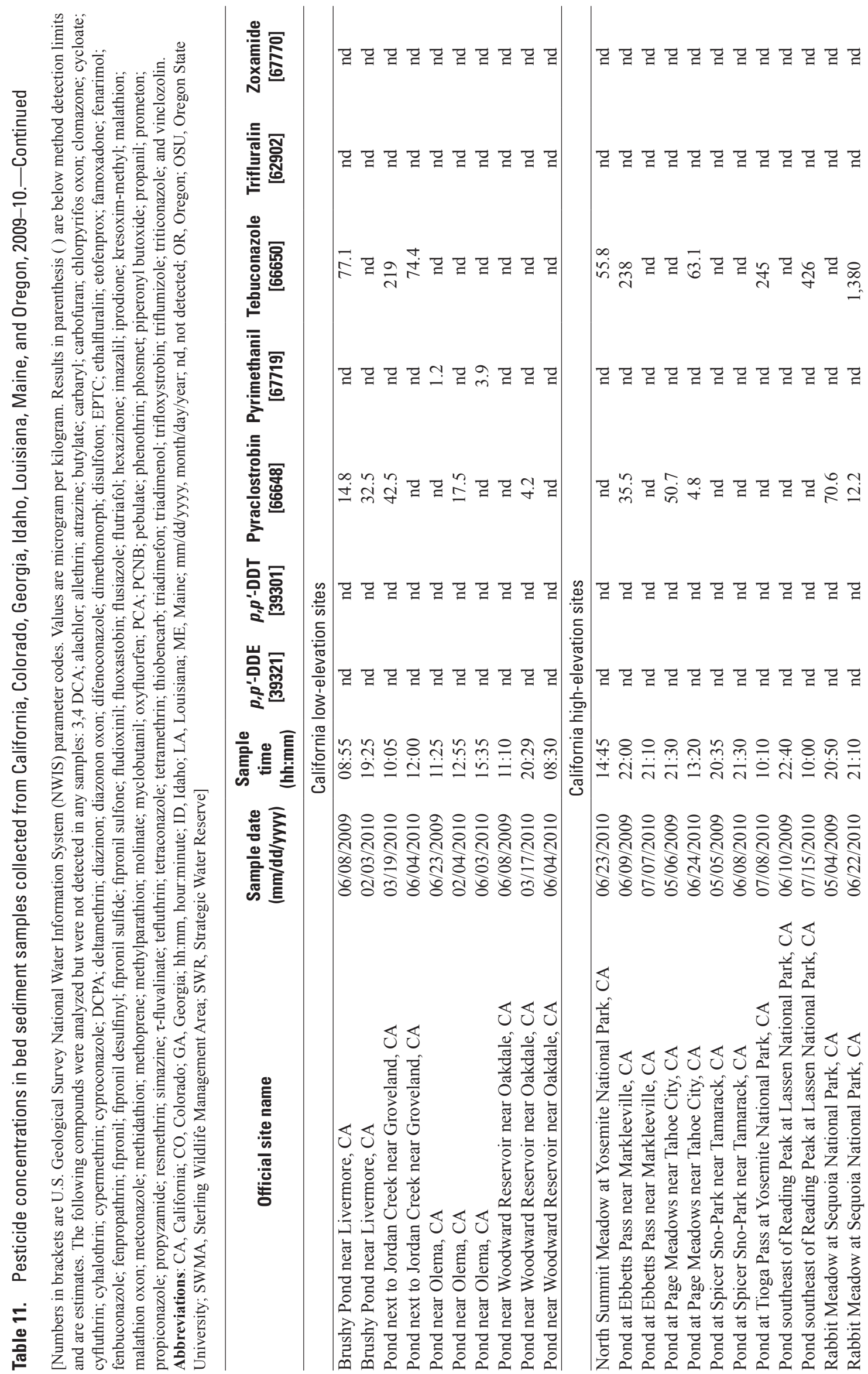




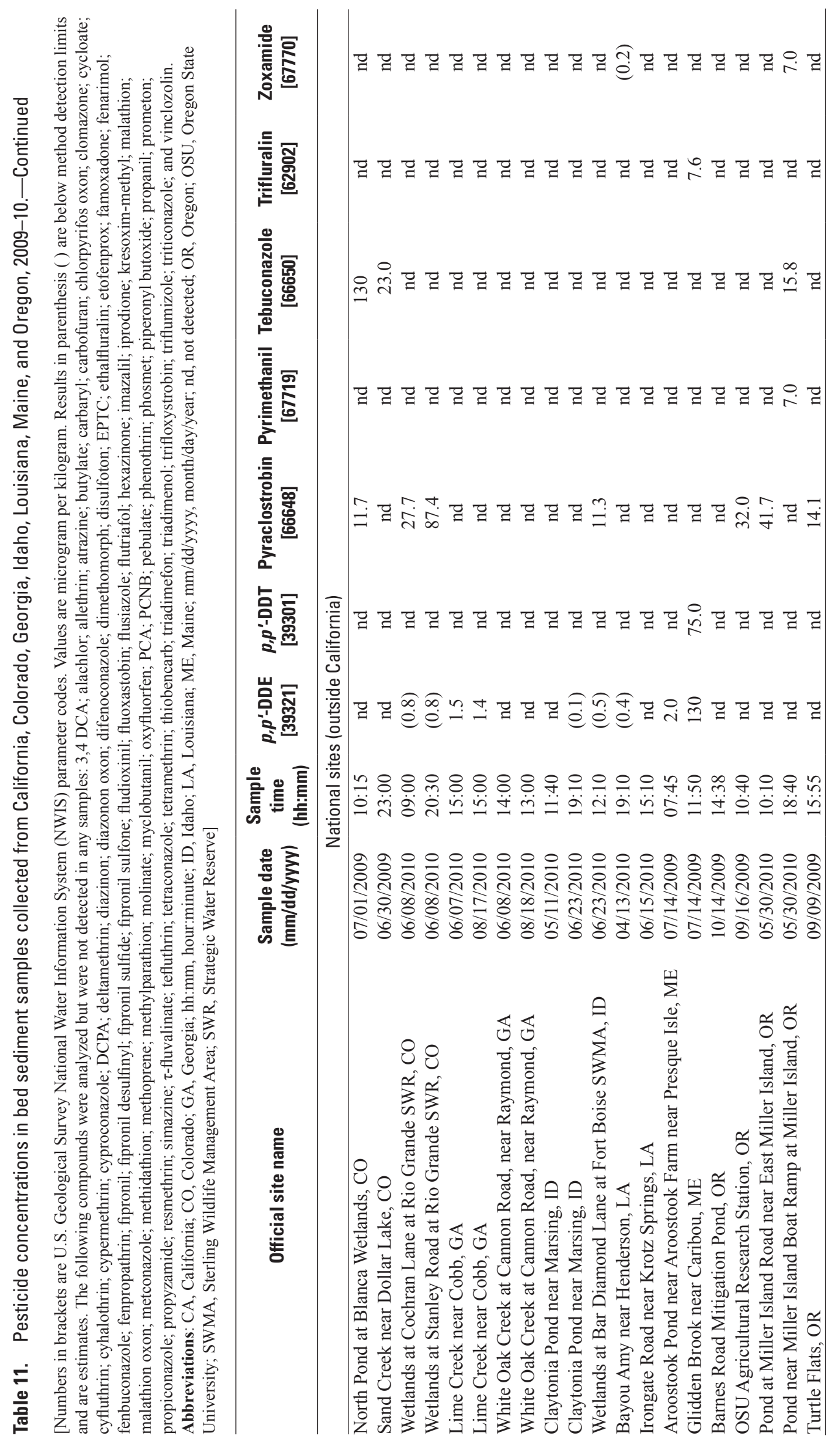


Of the seven pesticides detected at the high elevation sites compared to the seven detected at the low elevation sites, four were detected at both the low and high elevation sampling sites: bifenthrin, napropamide, pyraclostrobin, and tebuconazole. The six pesticides that were detected only at either low or high elevation sites (3,5-DCA, azoxystrobin, esfenvalerate, permethrin, prometryn, and pyrimethanil) had low frequencies of detection and only were observed at one or two sites during the sampling period. At the low elevation sites, pyraclostrobin was the most frequently detected pesticide at 50 percent, followed by bifenthrin at 40 percent, and tebuconazole at 30 percent. Tebuconazole was the most frequently detected pesticide at the high elevation sites at 50 percent, followed by pyraclostrobin at 42 percent and bifentrhin at 25 percent. Pesticide concentrations ranged from less than the method detection limit to $219 \mu \mathrm{g} / \mathrm{kg}$ (tebuconazole) at the low elevation sites and from less than the method detection limit to $1,380 \mu \mathrm{g} / \mathrm{kg}$ (tebuconazole) at the high elevation sites.

\section{Sediment Organic Carbon and Nitrogen}

Percent organic carbon and nitrogen ranged from 0.2 to 36.0 and 0.020 to 1.4 , respectively, in bed sediment collected from sites in the seven states (table 12). Organic carbon and nitrogen values in bed-sediment samples tended to vary by site and state.

\section{OA/QC Results for all Constituents Collected}

The results of the QA/QC measurements collected for this study show that the environmental data were of acceptable quality. All criteria used to evaluate the $\mathrm{QA} / \mathrm{QC}$ results were met, as described in the following sections.

\section{Dissolved Pesticides}

No pesticides were detected in any of the laboratory blank samples. Percent recovery of surrogates for all samples analyzed, including QC samples, ranged from 76 to 122 percent with a mean and standard deviation for ring $-{ }^{13} \mathrm{C}_{3^{-}}$ atrazine and diethyl $-\mathrm{d}_{10}$ diazinon of $90 \pm 8$ percent and $91 \pm 10$ percent, respectively. Relative percent difference between field replicate samples ranged from 3 to 20 percent. Laboratory matrix spike recoveries ranged from 75 to 122 percent with a median of 90 percent.

\section{Glyphosate, AMPA, and Glufosinate}

The compounds of interest were not detected in the laboratory blank samples. The relative percent difference of the field replicate samples ranged from 5 to 20 percent.

\section{Dissolved Organic Carbon}

Dissolved organic carbon in the laboratory blank samples was less than the method detection limit and was of acceptable quality. The relative percent difference of all replicate samples analyzed was less than 5 percent.

\section{Nutrients}

Inorganic constituents and nutrients were below method detection limits in all field blanks collected. Five replicate sample pairs were analyzed, and all analytes detected above method detection limits showed relative percent differences between the environmental and replicate sample of less than 20 percent.

\section{Batrachochytrium dendroibatidis $(\mathrm{Bd})$}

All data generated were of acceptable quality.

\section{Sediment-Associated Pesticides}

No pesticides were detected in any of the laboratory blank samples. Final surrogate recoveries in sediment ranged from 72 to 124 percent. The mean and standard deviation for recoveries of trifluralin- $\mathrm{d}^{10}$, ring- ${ }^{13} \mathrm{C}_{12}-p, p$, DDE, and phenoxy- ${ }^{13} \mathrm{C}_{6}$-cis-permethrin, which were used as recovery surrogates, were $84 \pm 9$ percent, $87 \pm 10$ percent and $97 \pm 13$ percent , respectively. Of the compounds detected in the replicate samples, relative percent differences ranged from 2.7 to 13.2 percent. Percent recovery in laboratory matrix-spiked samples ranged from 74 to 125 percent for all compounds. The mean and standard deviation for recoveries of $p, p^{\prime}-\mathrm{DDD}$ and $p, p^{\prime}-\mathrm{DDE}$ in SRM $1941 \mathrm{~b}$ were $84 \pm 10$ and $82 \pm 7$ percent, respectively. Measured concentrations for all compounds fell within the 95 percent confidence intervals for the certified values.

\section{Sediment Organic Carbon and Nitrogen}

The relative percent difference between the environmental and replicate samples ranged from 10 to 27 percent for organic carbon and ranged from 10 to 26 percent for nitrogen. 
Table 12. Percent organic carbon and nitrogen in bed sediment collected from California, Colorado, Georgia, Idaho, Louisiana, Maine, and Oregon, 2009-10.

[Abbreviations: CA, California; CO, Colorado; GA, Georgia; ID, Idaho; ME, Maine; OR, Oregon; OSU, Oregon State University; SWMA, Sterling Wildlife Management Area; SWR, Strategic Water Reserve]

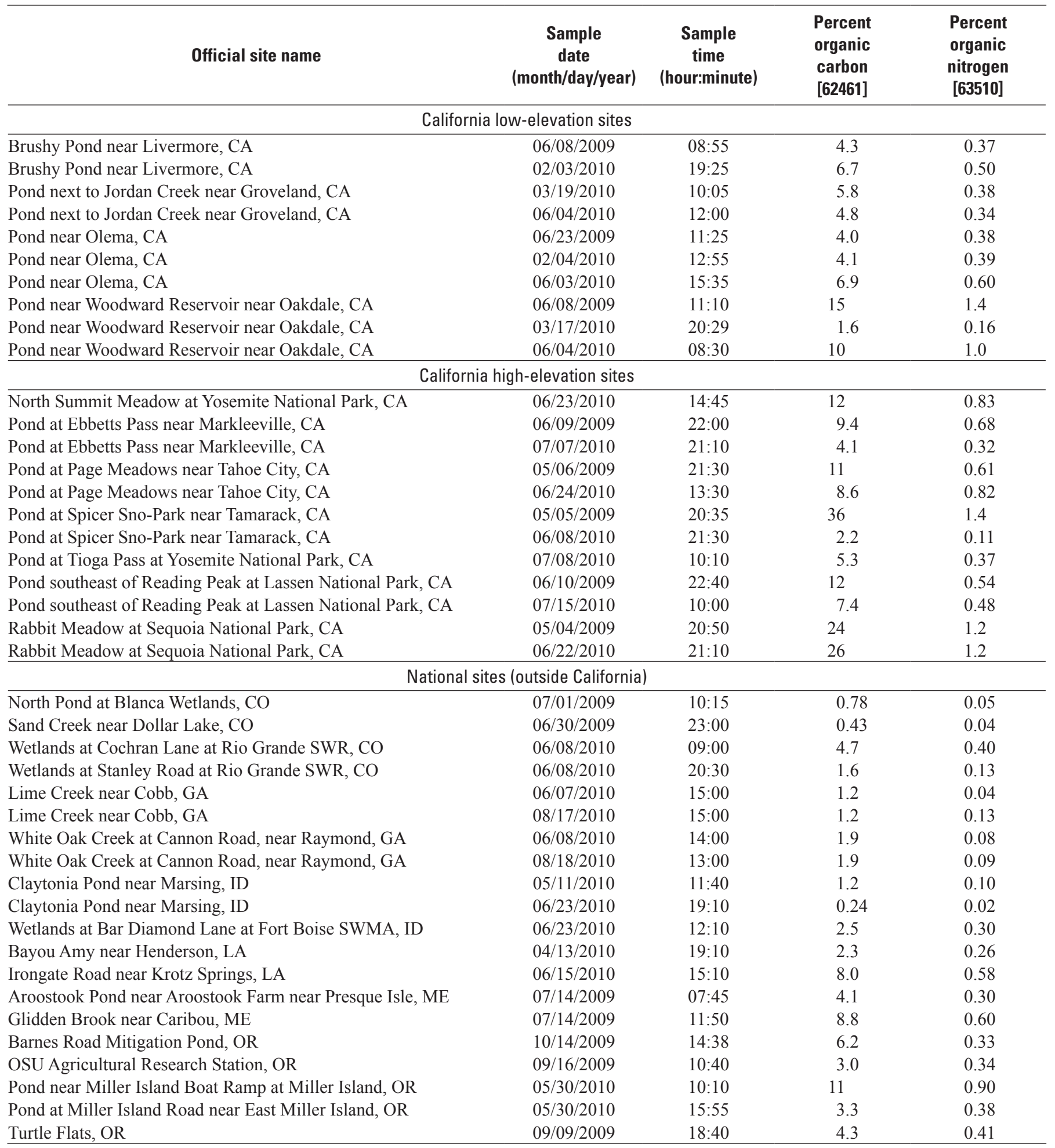




\section{Summary and Conclusions}

The study was designed to assess the presence of current-use pesticides in amphibian habitats across the nation in order to focus on potential exposure and facilitate further studies on pesticide accumulation in pond breeding frogs. The work described in this report is only a small portion of a greater project. In samples collected during 2009 and 2010, 24 different pesticides were detected in water, and 23 pesticides were detected in sediments.

Maximum pesticide concentrations in water samples ranged from less than the method detection limit to $2,880 \mathrm{ng} / \mathrm{L}$ (clomazone in Louisiana). On a National scale, the four most frequently detected pesticides in water samples included aminomethylphosphonic acid in 16 of 47 samples, glyphosate in 8 of 47 samples, and atrazine in 6 of 47 samples. In sites sampled within California, eight pesticides were detected that included two degradates, four herbicides, one insecticide, and one synergist. AMPA was the most frequently detected pesticide in samples from California at 15 percent, followed by glyphosate at 11 percent and prometon at 11 percent.

The fungus, Batrachochytrium dendrobatidis (Bd), was detected in four of the seven states, and Maine had the highest mean concentration of zoospores in a water sample with 343 zoospore equiv/L. Bd was detected most frequently in Idaho, where it was found in two of the three sites. In California, Bd was observed in surface-water samples from 7 of the 11 sites during the sampling period.

Maximum concentrations of pesticides in bed sediments ranged from less than their respective method detection limits to $1,380 \mu \mathrm{g} / \mathrm{kg}$ (clomazone). In bed-sediment samples collected from all seven states, the most frequently detected compounds were two fungicides, pyraclostrobin at 40 percent and tebuconazole at 29 percent, and a pyrethroid insecticide, bifenthrin at 36 percent. In sites sampled within California, the fungicides tebuconazole and pyraclostrobin were detected most frequently at 45 and 41 percent, respectively.

\section{Acknowledgments}

This project was funded by the USGS Amphibian Research and Monitoring Initiative (ARMI) and the USGS Toxics Substances Hydrology Program (Toxics). The authors acknowledge Kristi Jones, Megan McWayne Holmes, Corey Sanders, and Ryan Todd of the USGS for many hours of sampling and laboratory work. The authors also would like to thank the USGS Organic Geochemistry Research Laboratory in Kansas for glyphosate analysis and Julie Kirshtein (USGS, Reston, Va.) for Bd analysis in water. The authors also acknowledge Gary Fellers and Patrick Kleeman of the USGS Western Ecological Research Center for many hours of work in the field. Finally, the authors acknowledge the biologists, hydrologists, and students in Colorado, Georgia, Idaho, Louisiana, Maine, and Oregon for help in selecting and sampling sites to be included in the National-scale dataset.

\section{References Cited}

Belden, J., McMurray, S., Smith, L., and Reilley, P., 2010, Acute toxicity of fungicide formulations to amphibians and environmentally relevant concentrations: Environmental Toxicology and Chemistry, v. 29, p. 2477-2480.

Bird, S.M., Fram, M.S., and Crepeau, K.L., 2003, Method of analysis by the U.S. Geological Survey California District Sacramento Laboratory-Determination of dissolved organic carbon in water by high temperature catalytic oxidation, method validation and quality control practices: U.S. Geological Survey Open-File Report 03-366, 14 p.

Bradford, D.F., Knapp, R.A., Sparling, D.W., Nash, M.S., Stanley, K.A., Tallent-Halsell, N.G., McConnel, L.L., and Siminich, S.M., 2011, Pesticide distributions and population declines of California, USA, alpine frogs, Rana muscosa and Rana sierrae: Environmental Toxicology and Chemistry, v. 30, p. 682-691.

California Department of Pesticide Regulation, 2010, Pesticide use reporting system: Pesticide use data for 2009, [Digital data]: California Department of Pesticide Regulation.

Daszak, P., Cunningham, A.A., and Hyatt, A.D., 2003, Infectious disease and amphibian population declines: Diversity and Distributions, v. 9, p. 141-150.

Davidson, C., Shaffer, H.B., and Jennings, M.R., 2001, Declines of the California red-legged frog: Spatial analysis of climate, UV-B, habitat, and pesticides hypotheses: Ecological Applications, v. 11, p. 464-479.

Drost, C.A., and Fellers, G.M., 1996, Collapse of a regional frog fauna in the Yosemite area of the California Sierra Nevada, USA: Conservation Biology, v. 10, p. 414-425.

Fellers, G.M., and Drost, C.A., 1993, Disappearance of the Cascades Frog Rana cascadae, at the southern end of its range, California, USA: Biological Conservation, v. 65, p. $177-181$.

Fellers, G.M., McConnell, L.L., Pratt, D., and Datta, S., 2004, Pesticides in mountain yellow-legged frogs (Rana muscosa) from the Sierra Nevada mountains of California, USA: Environmental Toxicology and Chemistry, v. 23, p. 2170-2177.

Fishman, M.J., ed., 1993, Methods of analysis by the U.S. Geological Survey National Water Quality LaboratoryDetermination of inorganic and organic constituents in water and fluvial sediments: U.S. Geological Survey Open-File Report 93-125, 217 p.

Greulich, K., and Pflugmacher, S., 2003, Differences in susceptibility of various life stages of amphibians to pesticide exposure: Aquatic Toxicology, v. 65, p. 329-336. 
Greulich, K. and Pflugmacher, S., 2004, Uptake and effects of detoxification enzymes of cypermethrin in embryos and tadpoles of amphibians: Archives of Environmental Contamination and Toxicology, v. 47, p. 489-495.

Hippe, D.J., Hatzell, H.H., Ham, L.K., and Hardy, P.S., 1995, National Water-Quality Assessment Program: Pesticide occurrence and temporal distribution in streams draining urban and agricultural basins in Georgia and Florida, 1993-94: Georgia Water Resources Conference, Athens, Georgia, April 11-12, 1995, Proceedings: Hatcher, K.J., Ed., University of Georgia, available at http://www.gwri.gatech. edu/uploads/proceedings/1995/HippeD-HatzellH-HamLHardyP-95.pdf

Hladik, M.L., Smalling, K.L., and Kuivila, K.M., 2008, A multi-residue method for the analysis and pesticides and pesticide degradates in water using Oasis HLB solid phase extraction and gas chromatography-ion trap mass spectrometry: Bulletin of Environmental Contamination and Toxicology, v. 80, p. 139-144.

Homer, C., Dewitz, J., Fry, J., Coan, M., Hossain, N., Larson, C., Herold, N., McKerrow, A., VanDriel, J.N., and Wickham, J., 2007, Completion of the 2001 National Land Cover Database for the Conterminous United States: Photogrammetric Engineering and Remote Sensing, v. 73, p. 337-341.

Howe, C.M., Berrill, M., Pauli, B.D., Helbing, C.C., Werry, K., and Veldhoen, N., 2004, Toxicity of glyphosatebased pesticides to four North American frog species: Environmental Toxicology and Chemistry, v. 23, p. $1928-1938$.

Hughes, W.B. and Moon, C.L., 2009, Assessment of pesticides in urbanized watersheds of the Atlanta Metropolitan Area, Georgia, 2006-2008, Proceedings of the 2009 Georgia Water Resources Conference, Athens, Georgia,April 27-29, 2009, Proceedings accessed April 6, 2011, at URL http:// www.gwri.gatech.edu/uploads/proceedings/2009/7.2.3 Hughes.pdf

Kirshtein, J.D., Anderson, C.A., Wood, J.S., Longcore, J.E., and Voyteck, M.A., 2007, Quantitative PCR detection of Batrachochytrium dendrobatidis DNA from sediments and water: Diseases of Aquatic Organisms, v. 77, p. 11-15.

Lannoom, E., ed., 2005, Amphibian Declines: The Conservation Status of United States Species: University of California Press, Berkeley, California.

LeBlanc, L.A., Schroeder, R.A., Orlando, J.L., and Kuivila, K.A., 2004, Occurrence, distributionand transport of pesticides, trace elements and selected inorganic constituents into the Salton Sea Basin, California, 20012002: U.S. Geological Survey Scientific Investigations Report 2004-5117, 40 p.
Lips, K.R., Diffendorfer, J., Mendelson III, J.R., and Sears, M.W., 2008, Riding the wave: Reconciling the roles of disease and climate change in amphibian declines: PLoS Biology, v. 6, p. 441-454.

Longcore, J.R., Longcore, J.E., Pessier, A.P., and Halteman, W.A., 2007, Chytridiomycosis widespread in anurans of Northeastern United States: Journal of Wildlife Management, v. 71, p. 435-444.

Mann, R.M., Hyne, R.V., Choung, C.B., and Wilson, S.P., 2009, Amphibians and agricultural chemicals: Review of the risks in a complex environment: Environmental Pollution, v. 157, p. 2903-2927.

Meyer, M.T., Loftin, K.A., Lee, E.A., Hinshaw, G.H., Dietze, J.E., and Scribner, E.A., 2009, Determination of Glyphosate, its Degradation Product Aminomethylphosphonic Acid, and Glufosinate, in Water by Isotope Dilution and Online SolidPhase Extraction and Liquid Chromatography/Tandem Mass Spectrometry: U.S. Geological Survey Techniques and Methods, book 5, chap. A10, 32p.

Omernik, J.M., 1987, LeveI III Ecoregions of the United States: U.S. Environmental Protection Agency, Digital Data, available at http://www.epa.gov/wed/pages/ecoregions/ level iii_ iv.htm\#Level III

Ouellet, M., Bonin, J., Rodrigue, J., Desgranges, J.L., and Lair, S., 1997, Hindlimb deformities (ectromelia, ectrodactyly) in free-living anurans from agricultural habitats: Journal of Wildlife Diseases, v. 33, p. 95-104.

Pearl, C.A., Bull, E.L., Green, D.E., Bowerman, J., Adams, M.J., Hyatt, A., and Wente, W.H., 2007, Occurrence of the amphibian pathogen Batrachochytrium dendrobatidis in the Pacific Northwest: Journal of Herpetology, v. 41, p. 145-149.

Potter, B. B., and Wimsatt, J.C., 2005, Measurement of Total Organic Carbon, Dissolved Organic Carbon and Specific UV Absorbance at $254 \mathrm{~nm}$ in Source Water and Drinking Water: U.S. Environmental Protection Agency, Washington, DC, EPA/600/R-05/055, Method 415.3.

Reilly, T.J., Smalling, K.L., Orlando, J.L., and Kuivila, K.M., 2012, Occurrence of boscalid and other selected fungicides in surface water and groundwater in three targeted use areas in the United States: Chemosphere, v. 89, p. 228-234.

Relyea, R.A., 2005, The lethal impacts of Roundup ${ }^{\circledR}$ and predatory stress on six species of North American tadpoles: Archives of Environmental Contaminant Toxicology, v. 48, p. 351-357. 
Relyea, R.A., and Mills, N., 2001, Predator-induced stress makes the pesticide carbaryl more deadly to gray treefrog tadpoles (Hyla versicolor): National Academy of Sciences of the United States of America, Proceedings, v. 98, p. 2491-2496.

Rollins-Smith, L.A., 2009, The role of amphibian antimicrobial peptides in protection of amphibian from pathogens linked to global amphibian declines: Biochimica et Biophysica Acta - Biomebranes, v. 1788, p. 1593-1599.

Smalling, K.L., and Kuivila, K.M., 2008, Multi-residue method for the analysis of 85 current-use and legacy pesticides in bed and suspended sediments: Journal of Chromatography A, v. 1210 , p. 8-18.

Smalling, K.L., Orlando, J.L., and Kuivila, K.M., 2005, Analysis of pesticides in surface water and sediment from Yolo Bypass, California, 2004-2005: U.S. Geological Survey Scientific Investigations Report 2005-5220, 20 p.

Sparling, D.W., and Fellers, G., 2007, Comparative toxicity of chlorpyrifos, diazinon, malathion and their oxon derivatives to larval Rana boylii: Environmental Pollution, v. 147, p. 535-539.

Taylor, B., Skelly, D., Demarchis, L.K., Slade, M.D., Galusha, D., and Rabinowitz, P.M., 2005, Proximity to pollution sources and risk of amphibian limb malformation: Environmental Health Perspectives, v. 113, p. 1497-1501.
U.S. Department of Agriculture, 2010, Colorado Agricultural Statistics 2010: USDA NASS Colorado Field Office, Denver, Colorado, $55 \mathrm{p}$.

U.S. Environmental Protection Agency, 1992, Definition and procedure for the determination of the method detection limit-Revision 1.11: Code of Federal Regulations 40, Protection of the Environment, CFR Part 136, Appendix B, p. 565-567.

U.S. Fish and Wildlife Service, 2003, Alamosa - Monte Vista National Wildlife Refuge Complex Comprehensive Conservation Plan: U.S. Fish and Wildlife Service, Alamosa, Colorado, $157 \mathrm{p}$.

Vredenburg, V.T., Knapp, R.S., Tunstall, T.S., and Briggs, C.J., 2010, Dynamics of an emerging disease drive large-scale amphibian population extinction: National Academy of Sciences USA, Proceedings, v. 107, p. 9689-9694.

Woodhams, D.C., Hyatt, A.D., Boyle, D.G., and RollinsSmith, L.A., 2008, The northern leopard frog Rana Pipiens is a widespread reservoir species harboring Batrachochytrium dendrobatidis in North America: Herpetological Review, v. 39, p. 66-68.

Zimmerman, C.F., Keefe, C.W., and Bashe, J., 2007, Determination of carbon and nitrogen in sediments and particulates of estuarine/coastal waters using elemental analysis: U.S. Environmental Protection Agency Method 440.0, http://www.caslab.com/EPA-Methods/PDF/EPAMethod-440.pdf 
Publishing support provided by the U.S. Geological Survey Science

Publishing Network, Sacramento and Tacoma Publishing Service Centers

For more information concerning the research in this report, contact the Director, California Water Science Center

U.S. Geological Survey

6000 J Street, Placer Hall

Sacramento, California 95819

http://ca.water.usgs.gov 


\section{$\frac{1}{8}$}

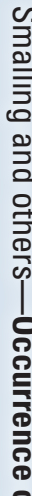

궁

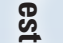

ㅎ.

罗

三'

幽

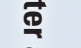

产

cs

竞

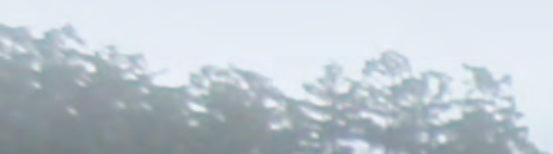

